University of Texas at El Paso

\title{
DigitalCommons@UTEP
}

Open Access Theses \& Dissertations

2016-01-01

\section{CEO Ownership and Firm Performance: Evidence from the 2003 Dividend Tax Cut}

Hong Kim Duong

University of Texas at El Paso, kimhongduong@yahoo.com

Follow this and additional works at: https://digitalcommons.utep.edu/open_etd

Part of the Accounting Commons, Business Administration, Management, and Operations $\underline{\text { Commons, Finance and Financial Management Commons, and the Management Sciences and }}$ Quantitative Methods Commons

\section{Recommended Citation}

Duong, Hong Kim, "CEO Ownership and Firm Performance: Evidence from the 2003 Dividend Tax Cut" (2016). Open Access Theses \& Dissertations. 640.

https://digitalcommons.utep.edu/open_etd/640 


\section{CEO OWNERSHIP AND FIRM PERFORMANCE: EVIDENCE FROM THE 2003 DIVIDEND TAX CUT}

\section{HONG KIM DUONG}

Doctoral Program in Business Administration

APPROVED:

Giorgio Gotti, Ph.D., Chair

David B. Farber, Ph.D.

Feixue Xie, Ph.D.

Charles Ambler, Ph.D.

Dean of the Graduate School 
Copyright (C)

by

Hong Kim Duong

2016 


\section{Dedication}

I would like to dedicate my dissertation to my mom, Nguyễn Thị Hiên, my husband, Ngô Đức Anh and my sons, Ngô Đức Minh and Ngô Hải Anh, for their support, love and care. Without them, pursuing this dream would be impossible. 


\title{
CEO OWNERSHIP AND FIRM PERFORMANCE: \\ EVIDENCE FROM THE 2003 DIVIDEND TAX CUT
}

\author{
by \\ HONG KIM DUONG, M.B.A.
}

\author{
DISSERTATION \\ Presented to the Faculty of the Graduate School of \\ The University of Texas at El Paso \\ in Partial Fulfillment \\ of the Requirements \\ for the Degree of
}

DOCTOR OF PHILOSOPHY

Doctoral Program in Business Administration

THE UNIVERSITY OF TEXAS AT EL PASO

December 2016 


\section{Acknowledgements}

I would like to thank Dr. Giorgio Gotti for being my mentor and chair of my dissertation.

I would not be able to complete this project without his invaluable support and guidance. Moreover, I would like to thank Dr. David B. Farber and Dr. Feixue Xie for being my dissertation committee members and guiding me throughout this dissertation project. 


\begin{abstract}
This study investigates whether and how CEO ownership impacts firm performance by using the large tax cut on individual dividend income enacted in 2003 (The 2003 Dividend Tax Cut) as an exogenous shock. My findings suggest that CEO ownership of dividend payers significantly increased after the shock in the form of higher annual restricted stock grants and more option exercises. I document that the change in CEO ownership has an asymmetric impact on firm performance and investment efficiency. Only dividend payers with CEOs who moved closer to optimal ownership experienced improvement in investment efficiency and performance. In contrast, dividend payers with CEOs who moved further away from optimal ownership experienced lower investment efficiency and had poorer performance. Overall, my findings provide insights to the design and efficacy of CEO compensation by showing that changes in CEO ownership lead to changes in firm performance.
\end{abstract}




\section{Table of Contents}

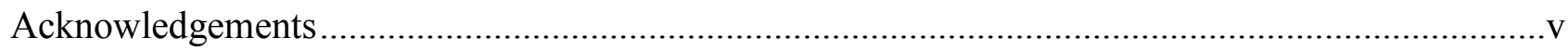

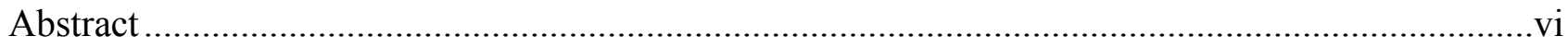

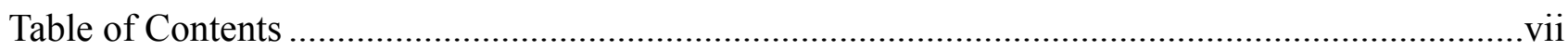

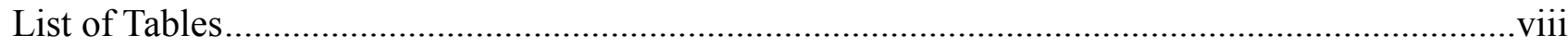

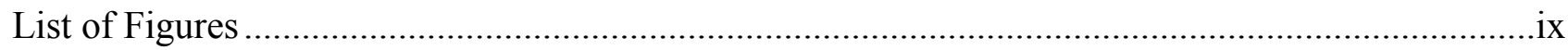

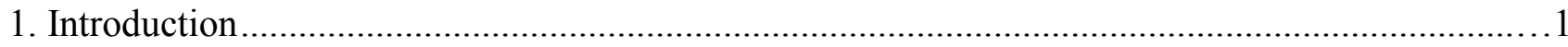

2. Prior Research and Hypothesis Development...................................................................... 10

2.1. Prior Literature on Executive Ownership and Firm Performance .................................10

2.2. The 2003 Dividend Tax Cut and Its Impacts on Corporate Behaviors ...........................14

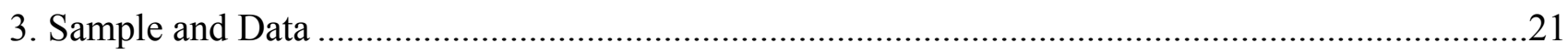

4. Changes in CEO Ownership around the 2003 Dividend Tax Cut............................................23

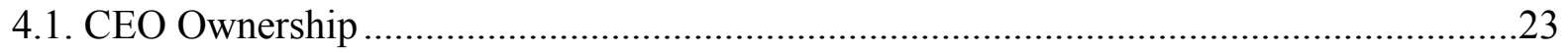

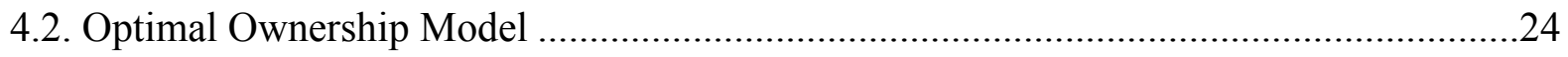

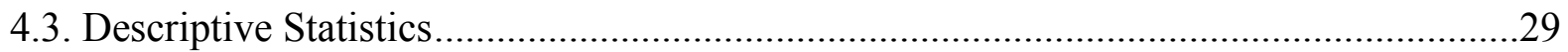

4.4. Changes in CEO Ownership around the 2003 Dividend Tax Cut................................32

4.5. Channels for the Changes in CEO Ownership..........................................................39

5. Changes in CEO Ownership and their Impacts on R\&D Investment, Investment Efficiency and Firm Performance

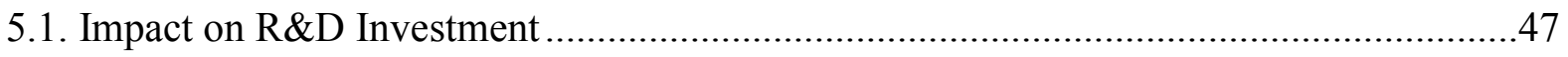

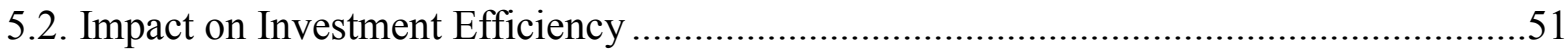

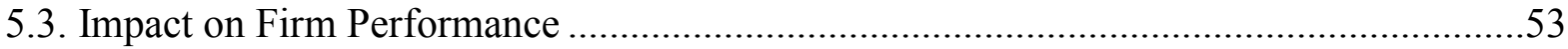

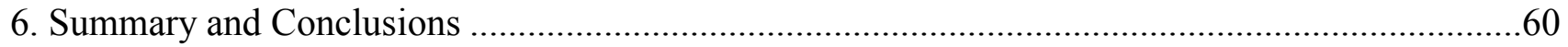

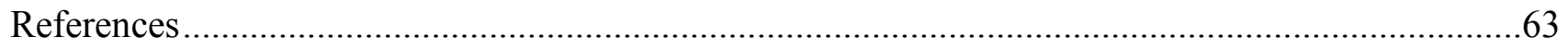

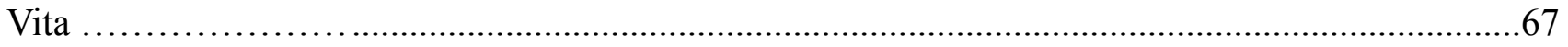




\section{List of Tables}

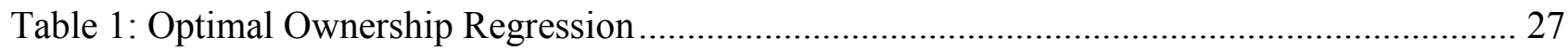

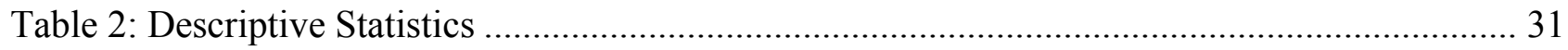

Table 3: Change in Actual CEO Ownership and CEO Ownership Deviation from Optimal Levels

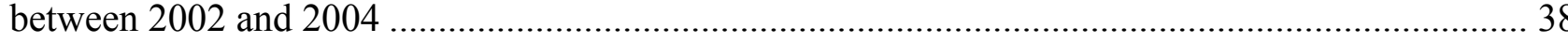

Table 4: Changes in CEO Ownership through New Stock and New Option Grants...................... 41

Table 5: Changes in CEO Ownership through Option Exercises and Open-market Trading

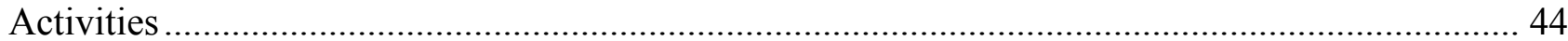

Table 6: Changes in CEO Ownership and R\&D Investment.............................................. 49

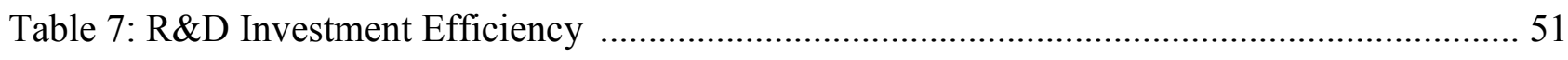

Table 8: Operating Performance - Excess ROA .............................................................. 55

Table 9: Stock Performance - Excess BHAR ..................................................................... 58 


\section{List of Figures}

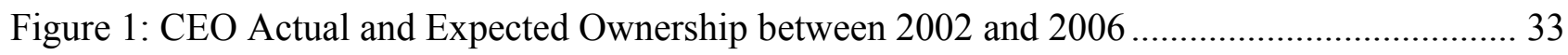

Figure 2: CEO Actual and Expected Ownership of Dividend Payers in More and Less Optimal

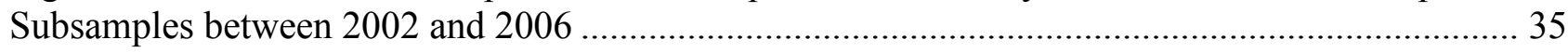




\section{Introduction}

Does Chief Executive Officer (CEO) equity ownership affect firm performance? While this question has received considerable attention in economics, finance and accounting research, it remains an open question. Studies on this issue employ two very different perspectives. One the one hand, Demsetz and Lehn (1985) assume that managerial ownership is endogenously determined. When contracting, firms would choose optimal ownership levels for their managers in accordance with the characteristics of the firms and the environment. Since the ownership is set at optimal, there should not be any relation between change in managerial ownership and change in firm performance. The empirical evidence in Himmelberg, Hubbard and Palia (1999) and in Coles, Lemmon and Meschke (2012) suggest that the relation between managerial ownership and firm performance is insignificant. They argue that their findings are consistent with the theoretical prediction in Demsetz and Lehn (1985) that firms optimally choose managerial ownership to maximize firm value when they contract with their CEOs. On the other hand, the incentive alignment hypothesis in Jensen and Meckling (1976) and the managerial entrenchment hypothesis in Stulz (1988) suggest that higher equity ownership is associated with better incentive alignment and lower entrenchment. Consistent with this prediction, Morck, Shleifer and Vishny (1988) find a non-linear relation between managerial ownership and firm performance.

Core and Guay (1999) attempt to reconcile these two perspectives and propose an alternative approach by relaxing some of the strong assumptions underlying these perspectives. They argue that firms choose optimal managerial incentives when they initially contract with managers. However, there is deviation from these optimal ownership levels over time due to high adjustment costs of continuously re-contracting. Thus, firm performance is expected to improve 
when firms re-optimize managerial ownership to move managerial ownership closer to its optimal level.

Consistent with the Core and Guay approach, prior research documents that firms that recontract with their CEOs improve CEO's incentives and firm performance. Core and Larcker (2002) examine a sample of firms that adopt "target ownership plans", under which executives are required to increase their equity ownership. Their findings suggest that after the adoption of these plans executive ownership increases significantly and these firms experience significant improvement in operating and stock performance. Cheng and Farber (2008) document that the proportion of CEOs' compensation in stock options declines significantly in the two years following earnings restatements. This reduction is followed by a decrease in the riskiness of investments and subsequent improvement in operating performance.

However, the findings about performance improvement after changes in executive ownership are subject to sample selection bias (Core and Larcker 2002, p.333; Cheng and Farber 2008, p.1244). Using econometric methods such as a matched sample or the Heckman (1979) two-stage procedure only mitigates the sample selection bias. Given the absence of exogenous variation, findings from prior research are subject to the criticism that the cross-sectional correlation between executive compensation and firm performance may reflect unobservable characteristics that generate both compensation policy and firm performance. A key contribution of my study is that I use an exogenous shock in the relative cost of holding equity that arises from the 2003 Dividend Tax Cut (DTC) to examine the relation between managerial ownership and firm performance. Doing so allows me to draw stronger inferences compared to prior research. 
In this paper, I use a large tax cut on individual dividend income enacted in the 2003 DTC included in the Jobs and Growth Tax Relief Reconciliation Act in 2003 as an unexpected and exogenous shock to investigate the association between CEO ownership and firm performance. Specifically, I aim to answer two main research questions. First, did CEO ownership increase after the 2003 DTC? Second, if CEO ownership did increase following the DTC, did this lead to improved firm performance?

The 2003 DTC significantly reduced the cost of receiving dividends for high income shareholders and thus increased the value of the stock holdings of firms that pay dividends (dividend payers). A reduction of individual dividend income tax from a top rate of 38.6 percent to 15 percent increased the after-tax value of a $\$ 1$ dividend of a high income shareholder from 61.4 cents to 85 cents, a 38 percent increase. Due to this favorable tax treatment, the value of dividend paying stocks increased significantly. I therefore expect that the 2003 DTC provided incentives for CEOs to hold higher equity ownership and for firms to grant more equity. Generally, changes in CEO ownership come from four channels: (1) new restricted stock grants; (2) new stock option grants; (3) vested option exercises by CEOs; and (4) CEO trading in the open market, including share sales and purchases. Changes in the first two channels are completed by the board of directors, while changes in the last two channels are completed by the CEOs. To provide more insights about how the 2003 DTC affected CEO ownership, I examine changes in CEO ownership associated with each of these four channels.

Using a balanced sample of 247 dividend payers and 297 non-dividend payers (as a control group) between the period 2002 and 2004 that have non-missing data for research and 
development expenditures $(R \& D)^{1}$, I find that CEO ownership of dividend payers significantly increased from 6.73 percent in 2002 to 11.41 percent in 2004 through higher restricted stock grants, more option exercises and higher net purchases. Dividend payers re-contracted with their CEOs in 2004 by granting more restricted stock $(\$ 417,738$ increased in new restricted stock grant value, which is equivalent to 4.08 percent of total compensation) but fewer stock options (\$753,680 decreased in new option grant value, which is equivalent to 11.22 percent of total compensation). ${ }^{2}$ From 2002 to 2004, CEOs of dividend payers exercised $\$ 2,612,540$ more options and owned \$6,413,440 more shares. This finding is in line with Aboody and Kasznik (2008) who find that firms with higher percentage of ownership by individual shareholders substitute restricted stock grants for option grants to induce managers to pay dividends.

After finding that the 2003 DTC did have positive impact on CEO ownership, I move on to examine the second research question, whether an increase in CEO ownership leads to improvement in firm performance. I follow the theoretical framework of Core and Guay (1999) and Core and Larcker (2002) and expect that more optimal ownership is associated with improvement in firm performance. A higher CEO ownership does not always leads to better performance. The risk associated with stock performance for CEOs is higher than outside investors because CEOs also have human capital and undiversified stock holdings of their own firms (Ofek and Yermack 2000). Therefore, a higher equity ownership might deter a CEO from

\footnotetext{
${ }^{1}$ I select the sample with no-missing data on $R \& D$ to serve two purposes. First, executive ownership plays significantly more important role in firms operating in noisier environment, has a significant amount of intangible assets and exposes to riskier investments such as research and development (Demsetz and Lehn 1985, p.1158-1160). Thus, using $R \& D$ investment sample provide stronger setting to examine the role of CEO ownership on firm performance. Second, using $R \& D$ investment sample allows me to examine the change in risk-taking behavior of CEOs measured as the change in $R \& D$ investment and the direct outcome of their $R \& D$ investment measured as the number patents granted (i.e. investment efficiency).

${ }^{2}$ A reduction in option grants is expected because both restricted stock and stock options provide equity incentives, but only stock holders receive any dividend paid on the stock whereas stock option holders do not receive the dividends until they exercise and hold the stock.
} 
investing in risky investment projects, such as $R \& D$ investment, even though those projects might have positive net present values.

First, I follow Core and Larcker (2002) to compute an ownership benchmark by constructing a regression model comparable to the models used by Himmelberg, Hubbard and Palia (1999) and Core and Larcker (2002), in which the dependent variable in the regression is the natural logarithm of CEO ownership. I used the change in optimal ownership deviation (Deviation) from 2002 and 2004 to determine whether an increase in equity ownership moves the CEO closer to or further from the optimal ownership level. Specifically, I use the difference between the absolute values of Deviation in 2002 and 2004 to separate the 247 dividend payers into two subsamples: More Optimal (114 CEOs) and Less Optimal (133 CEOs). CEOs belong to the More Optimal subsample if the absolute value of Deviation in 2002 is greater than the absolute value of Deviation in 2004. CEOs belong to Less Optimal subsample if the absolute value of Deviation in 2002 is less than the absolute value of Deviation in 2004. Prior to the shock of the 2003 DTC, CEOs in the More Optimal subsample under-owned their firms while CEOs in the Less Optimal subsample over-owned their firms. An increase in ownership after the 2003 DTC shock moved the CEOs in the More Optimal subsample closer to the optimal ownership levels but moved the CEOs in the Less Optimal subsample further from the optimal ownership levels.

Next, I examine whether more optimal ownership is associated with improvement in investment and firm performance. I examine the change in CEOs' risk taking behavior measured by the levels of $R \& D$ investment and the investment efficiency measured by the number of patents granted scaled by $R \& D$ investment. I first document a significant negative associated between changes in CEO ownership and changes in $R \& D$ investment and the negative 
association is more significant in the Less Optimal subsample. To conduct tests of changes in investment efficiency (IE), I follow Hirshleifer, Hsu and Li (2013) and define IE as a firm's ability to generate patents per dollar of $R \& D$. I allow a two-year lag between changes in $R \& D$ and patents granted because, on average, it takes two years for the United Stated Patent and Trademark Office (USPTO) to grant a patent application (Hall, Jaffe and Trajtenberg 2001). I measure $I E$ in 2006 and 2007 as the ratio of the total number of patents granted in 2006 and 2007 to the total accumulated $R \& D$ investments in 2004 and 2005, respectively. I find that only dividend payers in the More Optimal subsample experienced a significant improvement in investment efficiency. In contrast, dividend payers in the Less Optimal subsample experienced a reduction in investment efficiency.

Finally, I examine the change in firm performance of dividend payers in 2006 and 2007 and find that dividend payers in the More Optimal subsample consistently outperformed the operating performance measured as return to assets $(R O A)$ of their benchmark firms by the mean of 1.38 and 1.95 percentage points in 2004 and 2005, respectively. In contrast, dividend payers in the Less Optimal subsample underperformed their benchmark firms' ROA in both 2004 and 2005. The results using stock return performance measured by 12- and 24-month buy-and-hold returns $(B H A R)$ also suggest that more optimal ownership is associated with improvement in firm performance. Dividend payers in the More Optimal subsample beat their benchmark portfolios by the mean of 5.36 percent in 12-month BHAR and 7.57 percent in 24-month BHAR while dividend payers in the Less Optimal subsample insignificantly under-performed their benchmark portfolios. Overall, these findings suggest that more optimal ownership is associated with more efficient investment decisions and improvement in firm performance. 
This paper contributes to the extant literature in several important ways. First, and most importantly, this paper extends the literature on the relation between managerial equity ownership and firm performance. Using the 2003 DTC as an exogenous shock that provides a stronger econometric identification of the relation between managerial ownership and firm performance, I find that CEO ownership of dividend payers significantly increased after the 2003 DTC and that a movement toward a more optimal level of CEO ownership is significantly associated with more efficient R\&D investment and better firm performance. My finding that there is a significant association between changes in CEO ownership and firm performance sheds light on the debate about whether managerial ownership has any impact on firm performance (e.g., Demsetz and Lehn 1985; Himmelberg, Hubbard and Palia 1999; Morck, Shleifer, and Vishny 1988; Core and Guay 1999; Core and Larcker 2002).

Second, I provide empirical evidences on four different channels through which CEO ownership of dividend payers changed after the 2003 DTC: (1) new restricted stock grants; (2) new stock option grants; (3) option exercises; and (4) trading in open-market including share sales and purchases. My findings that dividend payers re-contract with their CEOs and rewarded more restricted stocks and reduced stock option grants are in line with the evidences documented in Aboody and Kasznik (2008). However, my study is different from Aboody and Kasznik (2008) because my focus is on the association between total CEO ownership and firm performance while Aboody and Kasznik (2008) focus on the association between annual equity grants and the total level of dividend payment. Aboody and Kasznik (2008) do not examine the impact of the 2003 DTC on CEO ownership through option exercises or trading in open-market.

Third, my findings that higher CEO ownership has an asymmetric impact of risky investment extend the findings documented in Coles, Daniel and Naveen (2006). In that study, 
the authors document a strong causal relation between managerial equity incentives and investment policy. They find that CEOs with higher option holdings, implying higher risk sensitivity to stock volatility, implement more investment in $R \& D$. I find that although dividend payers in the More and Less Optimal subsamples both significantly reduced option grants after the 2003 DTC, only dividend payers in the Less Optimal subsample reduced their investment in $R \& D$. My results suggest that the level of total CEO ownership and the distance to optimal ownership levels are important determinants of $R \& D$ investment policy. Furthermore, I directly test and provide evidence that more optimal ownership is also associated with more efficient $R \& D$ investment.

Last but not least, this study extends a growing literature on the impact of dividend taxes on corporate decisions. Prior search investigates the impact of the 2003 TDC on corporate payout structure (Chetty and Saez 2005, 2006; Brown, Liang, and Weisbenner 2007; Brav et al. 2008 and Blouin, Raedy and Shackelford 2011), market responses to dividend announcements and payments (Chetty, Rosenberg, and Saez 2005, Amromin, Harrison an Sharpe 2008), cost of equity capital of dividend payers (Auerbach and Hassett 2005, Dhaliwal, Krull and Li 2007 and Dai et al. 2013), tangible investment in capital expenditure (Campbell et al 2013) and the structure of CEO annual compensation (Aboody and Kasznik 2008 and Shevlin 2008). My study extends this stream of literature by investigating the impact of the 2003 DTC on total CEO ownership, as well as the economic consequences of these changes. To my best knowledge, this is the first study to examine the impact of the 2003 DTC on total equity ownership of CEOs.

The remainder of this paper is organized as follows. In Section 2, I provide an overview of the related literature and develop my hypotheses. In Section 3, I present my sample and data. Section 4 reports the empirical results for the change CEO equity ownership following the 2003 
DTC. In Section 5, I report empirical results for the impact of changes in CEO equity ownership on investment and firm performance. I summarize and conclude in Section 6. 


\section{Prior Research and Hypothesis Development}

This paper is related to prior studies that investigate the association between managerial equity ownership and firm performance and to the research that documents the impacts of the 2003 DTC on corporate behavior. Below, I briefly review these studies and develop my hypotheses for the change in CEO ownership after the 2003 DTC and then the economic consequences of changes in CEO ownership on firm performance.

\subsection{Prior Literature on Executive Ownership and Firm Performance}

The extant literature on the association between executive ownership and firm performance documents mixed evidence. On the one hand, Demsetz and Lehn (1985) predict that there is no relation between executive ownership and firm performance if firms can continuously re-contract. Their empirical evidence indicates that executive ownership is determined by firm performance, not vice-versa. Himmelberg, Hubbard, and Palia (1999) argue that fixed effects should be used when estimating the association between executive ownership and firm performance. Their findings indicate that after controlling for firm fixed effects, there is no relation between executive ownership and firm subsequent performance. Coles, Lemmon and Meschke (2012) employ a structural model approach to re-examine the association between executive ownership and firm performance and document evidences that are in line with conclusions of Demsetz and Lehn (1985) and Himmelberg, Hubbard, and Palia (1999).

On the other hand, the incentive alignment hypothesis in Jensen and Meckling (1976) and the managerial entrenchment hypothesis in Stulz (1988) suggest that higher equity ownership is associated with better incentive alignment and lower entrenchment. Morck, Shleifer, and Vishny (1988) assume that firms cannot contract optimally with their managers because the adjustment 
costs of re-contracting are so great. Consistent with the incentive alignment hypothesis of Jensen and Meckling (1976) and the managerial entrenchment of Stulz (1988), Morck, Shleifer, and Vishny (1988) find a nonlinear and significant relationship between managerial ownership and firm performance (measured as Tobin's Q). They find that Tobin's Q first increases (when managerial ownership is less than 5 percent), then declines (when managerial ownership is between 5 percent and 25 percent), and finally rises slightly as the managerial ownership increases. Zhou (2001) provides insightful comments on the fixed approach proposed in Himmelberg, Hubbard and Palia (1999). Zhou argues that although managerial ownership is substantially different across firms, the change in managerial ownership is slow from year to year within a company. By relying on time-series variation within a company, fixed effects estimators may not detect an effect of ownership on subsequent performance even when such a relation exists.

Core and Guay (1999) reconcile these two schools of thought and propose an alternative approach by relaxing some of the strong assumptions. They argue that firms choose optimal managerial incentives when they contract. However, overtime firms deviate from these optimal ownership levels due to high adjustment costs of continuously re-contracting. Thus, we would expect firm performance improvement when firms re-contract with their managers to move managerial ownership closer to optimal levels.

Core and Guay (1999) develop a model for the optimal level of CEO equity ownership and find that the optimal portfolio of incentives from stock and options varies with the hypothesized economic determinants specified in Demsetz and Lehn (1985) such as firm size, growth opportunities, and proxies for monitoring costs. CEO ownership gradually deviates from optimal levels, either because the optimal levels shift or because of changes in the incentives 
provided by CEO stock and option portfolios. Core and Guay (1999) also provide empirical evidence that firms not only set an optimal level of CEO incentives but also actively manage toward this level by varying incentive grants to correct deviations from these optimal incentive levels. Tong (2008) uses two events - share issuance and share repurchase, to examine the impact of executive ownership on subsequent performance. The implication is that share issuance (repurchase) will dilute (raise) the percentage of executive ownership. However, one limitation of Tong (2008) is that the decisions to issue or repurchase shares are also endogenously determined within firms and therefore the interpretation of his findings is constrained.

Core and Larcker (2002) and Cheng and Farber (2008) exploit the advantage of being able to find a set of firms that highlight the suboptimal level of CEO ownership to examine the relation between equity ownership and firm performance. Core and Larcker (2002) use a sample of firms that adopt "target ownership plans", under which mangers are required to increase their ownership levels (the implicit assumption is that these managers previously under-owned their firms), and show that an increase in managerial equity ownership is significantly associated with improvement in subsequent performance (measured as returns on assets and stock returns). Cheng and Farber (2008) use a sample of earnings restatement firms to examine whether firms re-contract with their CEOs in post-restatement years to adjust managerial equity incentives toward optimal levels. Their findings suggest that restatement firms re-contract with their CEOs by reducing option-based compensation and that more optimal incentives lead to significant improvement in subsequent performance. Although both Core and Larcker (2002) and Cheng and Farber (2008) find a significant association between managerial ownership and firm performance, the association is in opposite directions. Core and Larcker (2002) find that higher equity ownership (measured by stock ownership) is followed by better performance. In contrast, 
Cheng and Farber (2008) document that lower equity ownership (measured by lower option grants) is followed by better performance. The explanation for these divergent findings lies in the sample selection of each study. The sample in Core and Larcker (2002) include firms with managers who under-own their firms while the sample in Cheng and Farber (2008) include firms with managers who over-own their firms. It is worth to note that neither of these studies explicitly examines how the relative distance to optimal ownership levels affects firm subsequent performance.

Moreover, the findings about performance improvement after the change in executive ownership of Core and Larcker (2002) and Cheng and Farber (2008) are subject to sample selection bias (Core and Larcker 2002, p.333; Cheng and Farber 2008, p.1244). Using econometric methods such as matched sample or the Heckman (1979) two-stage procedure only mitigates the bias problem. Core and Larcker (2002) and Cheng and Farber (2008) share the absence of exogenous shock. Without an exogenous shock to managerial ownership, it would be difficult to identify a relation between managerial ownership and firm performance because the relation is endogenous. Given the absence of exogenous variation, any findings about the association between managerial ownership and firm performance are subject to the criticisms that such a relation may reflect unobservable factors that generate both managerial ownership and firm performance. This paper overcomes such a limitation and moves the literature forward by using the 2003 DTC as an unexpected and exogenous shock that provides a stronger econometric identification of the relations of interest. 


\subsection{The 2003 Dividend Tax Cut and Its Impacts on Corporate Behaviors}

On May 23, 2003, the U.S. Congress approved the Jobs and Growth Tax Relief Reconciliation Act of 2003. On May 28, 2003, President George W. Bush signed the 2003 TDC into law. The 2003 DTC sharply reduced the cost of receiving dividends and capital gains for high income shareholders and thus, increases the value of the stock holdings of firms that pay dividends (dividend payers). A reduction of individual dividend income tax from a top rate of 38.6 percent to 15 percent raise the after-tax value of a $\$ 1$ dividend of a high income shareholder from 61.4 cents to 85 cents, a 38 percent increase. The maximum tax rate on capital gains also fell from 20 percent to 15 percent. The rationale of the 2003 DTC was that lower tax rates on dividends would promote investment, spur growth and create more jobs (White House 2003). The passage of the 2003 DTC was considerably uncertain because it passed the House of Representatives on May 9, 2003 by a vote of 222 to 203 and the bill passed the Senate on May 23,2003 with the narrowest possible margin of a 51 to 50 vote.

Several studies have used the 2003 DTC as a natural experiment to learn about the economic effects of dividend taxation and documented the impacts of the 2003 DTC on corporate payout policy. Chetty and Saez (2005) find an unusually large number of firms initiated or increased regular dividend payments in one year after the tax reform. Brown, Liang, and Weisbenner (2007) investigate whether executive equity ownership affects firm payouts and find that executives with higher ownership were more likely to increase dividend after the 2003 DTC, whereas no relation is found for the periods before the tax reform. Blouin, Raedy and Shackelford (2011) find that directors rebalanced their portfolios to maximize after-tax returns to respond to the 2003 TDC. Together, the findings in Chetty and Saez (2005), Brown, Liang, and Weisbenner (2007) and Blouin, Raedy and Shackelford (2011) suggest that executives quickly 
responded to the sharp change in the tax treatment of dividend income in 2003 by increasing the levels of dividend payment and their stock holdings. Aboody and Kasznik (2008) find that after the 2003 DTC, dividend payers increased the proportion of annual restricted stock grants and reduced the proportion of annual stock options grant to induce CEOs to pay more dividends. Overall, the findings in prior literature indicate that there are two sources that increase the value of holding stocks that pay dividend. The first source comes from more favorable tax treatment. And the second source comes from an increase in dividend amount. Therefore, I expect that the 2003 DTC will have a positive impact on CEO ownership.

The prior discussion leads to my first hypothesis, stated in the alternative form, as follows:

H1: CEO ownership of dividend payers significantly increased from 2002 to 2004.

Generally, the change in CEO ownership comes from new restricted stock grants, new stock option grants, vested option exercises and trading in open-market including share sales and purchases. ${ }^{3}$ It is possible that I may not find supporting evidences for the first hypothesis. If CEOs actively rebalance their equity holdings by selling previously owned shares to diversify the unsystematic risk associated with concentrating wealth in their firms, the sales will negate the impact of new equity grants. Thus, whether new equity grants lead to higher CEO equity ownership also depends on how much equity ownership is rebalanced by the CEOs. Ofek and Yermack (2000) investigate the impact of stock-based compensation on managerial ownership by comparing inflows of equity to managers' portfolios from newly granted restricted shares, newly granted options, and option exercises and outflows of equity from sales of stock and sales

\footnotetext{
${ }^{3}$ The dynamics of equity flows is presented in more details in Figure 2 in Cheng and Warfield (2005, p.446)
} 
of stocks converted from option exercises. Their findings suggest that new equity compensation only succeeds to increase incentives of low-ownership managers. High-ownership managers actively sell previously owned shares right after receiving new restricted stocks and stock option grants. For every 1,000 new options awards, high-ownership managers, on average, sell 684 previously owned shares to reduce undiversified risk associated with wealth concentration. Moreover, Ofek and Yermack (2000) also find that for executives who exercise stock options, regardless of the level of prior ownership, almost all the new shares are disposed. It means that if CEOs sell their previously owned shares and the number of shares in the sales is greater than the total number of shares they receive from new equity grants and from option exercises, the total CEO ownership will decrease. Thus, whether CEOs choose to diversify away the unsystematic risk associated with a greater concentration of wealth in their firm's stocks by selling previously owned shares, or to accept higher risk exposure associated with wealth concentration to receive the favorable treatment of the 2003 DTC appears to be an empirical question.

Similarly, option exercises may or may not influence total CEO ownership. On the one hand, if CEOs exercise vested options and keep the shares received from option exercises, their equity ownership will rise. On the other hand, if CEOs exercise vested options and dispose all the shares acquired from option exercises, their equity ownership will fall. The empirical evidences in Ofek and Yermack (2000) suggest that regardless of their prior ownership level, all executives who exercise stock options dispose of almost all of the shares acquired. Again, whether CEOs choose to diversify away the unsystematic risk associated with a greater concentration of wealth in their firm's stocks by disposing of the shares received from option exercises, or to accept higher risk exposure by keeping those shares converted from options to receive the favorable treatment of the 2003 DTC is still an empirical question. 
Recall that the main purpose this study is to re-examine the relation between CEO equity ownership and firm performance in a natural experiment of the tax reform - the 2003 DTC. Suppose that I find evidences that the 2003 DTC did have a positive impact on CEO ownership, the next question that arises is whether and how changes in CEO ownership lead to changes in firm performance.

To answer how changes in CEO ownership would lead to changes in firm performance, I use $R \& D$ investment as a channel through which ownership would influence firm performance. My selection of $R \& D$ investment channel is based on the theoretical prediction of Demsetz and Lehn (1985) and empirical evidences in prior research such as Coles, Daniel and Naveen (2006), Core and Guay (1999), Rajgopal and Shevlin (2002) and Cheng and Farber (2008).

Demsetz and Lehn (1985) argue that executive ownership plays a more significant and important role in determining firm performance when firms operate in a noisy environment, high information asymmetry, or invest heavily in risky projects and intangible assets (Demsetz and Lehn 1985, p.1158-1160). Since most of the investment in $R \& D$ is intangible assets, $R \& D$ firms are considered to have high information asymmetry, managerial discretion and presumably high agency problem. To control for agency problem, $R \& D$ firms tend to rely more on ownership than other corporate governance such as board of director (Demsetz and Lehn 1985).

Coles, Daniel and Naveen (2006) examine the relation between changes in CEO equity incentives and risk-taking behavior, measured by $R \& D$ investment. Their findings suggest that CEOs increase $R \& D$ investment when their wealth becomes more sensitive to their firm stock volatility. Controlling for the level of stock holdings, a compensation structure that contains more options would lead to higher sensitivity to stock volatility, and therefore would encourage 
CEOs to increase risky investment. They also document that controlling for sensitivity to stock volatility, a compensation structure that contains more stocks would lead to lower $R \& D$ investment.

Core and Guay (1999) and Rajgopal and Shevlin (2002) provide theoretical framework and empirical evidence that stock-based compensation is designed to induce managers to take a desired level of effort and to increase risk taking incentives. Changes in equity ownership, thus, will lead to changes in risk taking decisions of managers. Cheng and Farber (2008) argue that "restatement firms had excessive risky investments in the pre-restatement period due to high level of equity compensation and that the reduction in option compensation in the postrestatement period decreased the level of these investments" (Cheng and Farber 2008, p.1244).

Based on the argument and evidences documented in prior research, I expect to find changes in risk-taking behavior, measured by $R \& D$ investment, of the CEOs of dividend payers in my sample, after the 2003 DTC. The evidences documented in Coles, Daniel and Naveen (2006) suggest that the relation between changes in CEO equity ownership and R\&D investment could be positive or negative, depending on the relative proportion of CEO stock and stock options holdings.

If there is an increase in CEO ownership after the 2003 DTC and such an increase comes from the form of higher stock options, then I would expect to find an increase in the level of risky investments. However, if CEO ownership increases because CEOs have higher level of restricted stock holdings then I would expect to find a decrease in the level of risky investments, ceteris paribus. Since the changes in CEO ownership and $R \& D$ investment could go in either positive or negative direction, I do not have a directional prediction in advance and let the data 
shows us empirical evidences. This leads to my second hypothesis, stated in the alternative form, as follows:

H2: Changes in CEO ownership are associated with changes in the level of risky investments.

Core and Guay (1999) argue that due to the changes in economic determinants of managerial optimal ownership levels and the costs of continuously re-contracting, managerial ownership may not always be optimal. It means that CEOs may over- or under-own their firms at a certain point. If the exogenous shock of the 2003 DTC had a positive impact of CEO ownership, the level of some CEO ownership would move closer to the optimal levels if these CEOs under-owned their firms prior the shock, while some other CEO ownership levels - of those CEOs who over-owned or owned the optimal level of their firms prior to the shock would then [post shock] deviate from the optimal levels. Based on the prediction of Core and Guay (1999) optimal ownership model and the empirical evidences in Core and Larcker (2002) and Cheng and Farber (2008), I expect to find that dividend payers whose CEO ownership moves closer to the optimal levels after the shock will experience an improvement in subsequent investment and firm performance, but dividend payers whose CEO ownership deviates from the optimal after the shock will experience deterioration in subsequent investment and firm performance. This argument leads to third hypothesis, stated in the alternative form, as follows:

H3: More optimal CEO ownership is associated with higher investment efficiency.

Finally, to answer the question whether changes in CEO ownership are associated with changes in firm performance, I extend the findings in Hirshleifer, Hsu and Li (2013) and argue that more optimal CEO ownership leads to improvement in firm performance through an 
improvement in investment efficiency. This argument leads to my fourth and last hypothesis, stated in the alternative form, as follows:

H4: Higher investment efficiency is associated with improvement in firm performance. 


\section{Sample and Data}

I obtain a balanced sample of CEOs with no missing total compensation data from the Execucomp database. ${ }^{4}$ I use financial statement data from Compustat North America and stock return data from Center for Research in Security Prices. I exclude financial and utility firms and firms with missing data on total assets and $R \& D$ expenses. I select the sample with no-missing data on $R \& D$ to serve two purposes. First, executive ownership plays significantly more important role in firms operating in noisier environment, has a significant amount of intangible assets and exposes to riskier investments such as research and development (Demsetz and Lehn 1985, p.1158-1160). Since most of the investment in $R \& D$ is intangible assets, $R \& D$ firms are considered to have high information asymmetry, managerial discretion and presumably high agency problem. To control for agency problem, $R \& D$ firms tend to rely more on ownership than other corporate governance such as board of director (Demsetz and Lehn 1985). Thus, using $R \& D$ investment sample provide stronger setting to examine the role of CEO ownership in firm performance. Second, using $R \& D$ investment sample enables me to test the last two hypotheses by examining the change in risk-taking behavior of CEOs measured as the change in $R \& D$ investment and the direct outcome of their $R \& D$ investment measured as the number of patents granted.

To estimate the optimal ownership model, I limit the sample period between 2002 and 2006 because I aim to investigate the change in CEO ownership in one year pre and post the 2003 DTC and investigate the one and two years post investment and performance consequences of the change in CEO ownership. After these screening procedures, my final sample consists of

\footnotetext{
${ }^{4}$ I keep the sample balanced (constant) over the sample period between 2002 and 2006 to eliminate the impact of CEO turn-overs and change in dividend payout policy such as dividend initiation or omission on executive compensation, investing decisions and firm performance. Thus, balanced sample provides a stronger setting to test my hypotheses.
} 
2,720 CEO-year observations from 544 unique firms in 41 industries between 2002 and 2006. The sample consists of 1,235 CEO-year observations from 247 unique dividend payers and 1,485 CEO-year observations from 297 unique non-dividend payers. In the test for Hypotheses 3, I further limit my sample to firms that have available patent data shared by Professor Amit Seru from The University of Chicago. ${ }^{5}$ All continuous variables are winsorized at the top and bottom percentiles.

\footnotetext{
${ }^{5}$ https://iu.app.box.com/patents
} 


\section{Changes in CEO Ownership around the 2003 Dividend Tax Cut}

This Section presents the research design and the test results of the first hypothesis.

\subsection{CEO Ownership}

I follow Core and Guay (1999) and define CEO ownership as the natural logarithm of the proportion of shares outstanding held by a CEO plus the proportion of shares outstanding in options held by a CEO times the Black-Scholes hedging delta.

$$
\text { Ownership }=\log \left[\frac{\# \text { Shares }+\# \text { Options } \times \text { Delta }}{\# \text { CommonShares }}\right]
$$

where, \#Shares is the total number of shares held by CEO, \#Options is the total number of options outstanding held by CEO, \#CommonShares is the total number of common shares outstanding, and Delta is the Black-Scholes hedging delta, computed as:

$$
\begin{aligned}
& \text { Delta }=\frac{\partial \text { OptionValue }}{\text { PPrice }}=e^{-d T} N(Z) \\
& Z=\left[\log (S / X)+T\left(r-d+\delta^{2} / 2\right)\right] / \delta T^{1 / 2}
\end{aligned}
$$

where $N$ is the cumulative probability function for the normal distribution, $S$ is the price of the underlying stock, $X$ is the exercise price of the option, $\delta$ is the expected stock-return volatility over the life of the option, $r$ is the risk-free interest rate that I obtained from the Federal Reserve on their website for "Treasury constant maturities",$T$ is time to maturity of the options in years, and $d$ is the expected dividend rate over the life of the option.

\footnotetext{
${ }^{6}$ http://www.federalreserve.gov/releases/h15/data.htm
} 


\subsection{Optimal Ownership Model}

I compute an ownership benchmark by constructing a regression model comparable to those models used by Himmelberg, Hubbard and Palia (1999) and Core and Larcker (2002) where the dependent variable in the regression is the natural logarithm of CEO ownership. "This transformation enables us to interpret the residuals as the percentage by which actual ownership deviates from expected ownership" (Core and Larcker 2002, p.326).

The benchmark model for the level of managerial ownership is as follow: ${ }^{7}$

$$
\begin{aligned}
& \text { Ownership }_{i t}=\beta_{0}+\beta_{1} \text { Size }_{i t}+\beta_{2} \text { Size }_{i t}^{2}+\beta_{3} \text { Volatility }_{i t}+\beta_{4} \text { Volatility }_{i t}^{2}+\beta_{5} P P E_{i t}+\beta_{6} \text { RDAdvertise }_{i t} \\
& +\beta_{7} \text { CashFlow }_{i t}+\beta_{8} \text { MTB }_{i t}+\beta_{9} \text { Leverage }_{i t}+\text { YearDummies }+ \text { IndustryDummies }+\varepsilon_{i t}
\end{aligned}
$$

where Ownership is defined as the natural logarithm of the sum of the proportion of shares outstanding plus the proportion of shares outstanding in options times the Black-Scholes delta hedge ratio, specified in Equation 1. Size is natural logarithm of total market value where market value is the product of total common shares outstanding and the market price at fiscal year-end. Volatility is the annualized standard deviation of stock returns estimated over the 60 months prior to the beginning of the fiscal year. PPE is the ratio of plant, property and equipment to total assets. $R \& D$ and Advertising is the ratio of the sum of research and development expenses and advertising expenses to total assets. Cash Flow is the ratio of operating cash flows to total assets. $M T B$ is the ratio of total market value to total assets. Leverage is total debts divided by total

\footnotetext{
${ }^{7}$ I do not include firm fixed effects because Zhou (2001) argues that firm fixed effects estimators may not detect an effect of ownership on subsequent performance even when such a relation exists. I also estimated the ownership model specified in Core and Larcker (2002, p.327) but the explanatory power of their model in our sample is much lower (9.2 percent). Thus, I follow the suggestions of Himmelberg, Hubbard and Palia (1999) and Zhou (2001) to include more explanatory variables into the model. These variables are Size squared to capture the non-linear relation between ownership and firm size, PPE, RDAdvertise, Cash Flow and Leverage to capture the monitoring costs and the agency costs of free cash flows.
} 
assets. Year Dummies are year binary indicator variables for 2002 to 2005. Industry Dummies are 40 industry indicator variables.

I expect to find a negative coefficient for Size because the same proportion of ownership becomes more expensive and thus more difficult to hold when firm size increases $\left(\beta_{1}<0\right)$. Similar to Core and Larcker (2002), I also expect that managerial ownership will increase at a decreasing rate as monitoring costs increase $\left(\beta_{3}>0\right.$ and $\left.\beta_{4}<0\right)$. The squared terms of Size and Stock return volatility are included in the model to capture their non-linear relation with ownership (Core and Larcker 2002). Investment in fixed capital is observable and easier to monitor. Thus, similar to Himmelberg, Hubbard and Palia (1999), I expect to find lower managerial ownership in firms with a greater concentration of fixed or "hard" capital in their investments as measured by PPE $\left(\beta_{5}<0\right)$. I do not have a predicted sign for $R \& D$ and Advertise ( $\left.\beta_{6}\right)$ because $R \& D$ and Advertise could be positively or negatively associated with managerial ownership. If we consider $R \& D$ and Advertise as less observable investments, and more difficult to monitor, then a positive relation between $R \& D$ and Advertise and managerial ownership is expected. However, higher managerial ownership may also motivate a manager to reduce expenditure in risky investment such as $R \& D$ and Advertise to unload undiversified risk associated with the performance of their firm stock. As suggested by Jensen (1986), firms with more cash flows are more likely to have higher agency costs and require higher levels of monitoring ownership. Thus, I expect to find a positive coefficient of Cashflow $\left(\beta_{7}>0\right)$. Similar to Himmelberg, Hubbard and Palia (1999) and Core and Larcker (2002), I use MTB as proxy for growth opportunities and expect that firms with greater growth opportunities will require higher levels of ownership $\left(\beta_{8}>0\right)$. I do not have a predicted sign for Leverage $\left(\beta_{9}\right)$ because this variable can be either negatively or positively related to managerial ownership. On the one hand, 
Leverage can be a monitoring tool to reduce the agency cost of free cash flows and therefore reduce the desired level of managerial ownership (Jensen 1986). On the other hand, high ownership managers may become entrenched when they have more power in their firm (Morck, Shleifer and Vishny 1988), and therefore, firms use more debts as a monitoring tool to balance the entrenchment costs. To control for industry factors, I include industry dummies. To capture potential temporal differences in managerial ownership, I include year dummies.

I define Deviation as the absolute value of the residuals obtained from Equation 4 then use the difference in absolute values of Deviation in 2002 and 2004 to separate the 247 dividend payers into two subsamples: More Optimal (114 CEOs) and Less Optimal (133 CEOs). CEOs belong to More Optimal subsample if the absolute value of Deviation in 2002 is greater than the absolute value of Deviation in 2004. CEOs belong to Less Optimal subsample if the absolute value of Deviation in 2002 is less than the absolute value of Deviation in 2004. This research design allows me to capture the changes in ownership and Deviation of ownership in 2004 compared to 2002 as well as the cross-sectional variation in the changes in ownership and Deviation of ownership. ${ }^{8}$

Since this is a two-stage methodology, one may concern whether the model specification from the first stage is appropriate. I acknowledge the debate in the extant literature about the determinants of managerial ownership. Himmelberg, Hubbard and Palia (1999) suggest including firm fixed effects while Zhou (2001) points out some drawbacks of the firm fixed effects model and argues that firm fixed effects estimators may fail to detect an effect of ownership on firm performance even when such a relation exists because managerial ownership

\footnotetext{
${ }^{8}$ Since the passage of the 2003 DTC was not anticipated until May of 2003 and changes in executive compensation contracts are usually determined at fiscal year ends, it is unlikely that managers would fully respond to the change in legislation in 2003. That is why my one year pre- and post-event is 2002 and 2004, accordingly.
} 
changes slowly over time. Resolving this debate is beyond the scope of this study. The model specification in the first stage to estimate the expected CEO ownership level is based on the theoretical models of Core and Larcker (2002) and Himmelberg, Hubbard and Palia (1999), but excluding firm fixed effects (as suggested by Zhou 2001). My model specified in Equation 4 shares a similar limitation with the models of Core and Larcker (2002) and Himmelberg, Hubbard and Palia (1999) and is subject to the criticism of the omitted variable problem because we cannot exhaust the possibilities of omitted variables in any empirical specification.

To mitigate the problem of omitted variables, I conduct the second-stage analysis using difference-in-difference approach. If there is a variable omitted from Equation 4, it is unlikely that this variable has the exact cross-sectional variation with the change in CEOs ownership and change in firm performance in both the sample of interest (dividend payers) and the control group sample (non-dividend payers).

Table 1: Optimal Ownership Regression

\begin{tabular}{|c|c|c|c|}
\hline \multirow[b]{2}{*}{ Independent variable } & \multirow[b]{2}{*}{ Predicted sign } & \multicolumn{2}{|c|}{ Dependent variable } \\
\hline & & Ownership & $t$-statistics \\
\hline Size & - & $-0.676^{* * *}$ & -4.45 \\
\hline Size squared & & 0.006 & 0.67 \\
\hline Stock return volatility & + & $2.364 * * *$ & 3.56 \\
\hline Stock return volatility squared & - & $-1.337 * * *$ & -2.49 \\
\hline$P P E$ & - & -0.275 & -1.14 \\
\hline$R \& D$ and Advertising & $+/-$ & -0.861 & -1.46 \\
\hline Cash flow & + & 0.095 & 0.21 \\
\hline MTB & + & 0.009 & 0.18 \\
\hline Leverage & $+/-$ & 0.223 & 1.15 \\
\hline Industry fixed effects & & & \\
\hline Year fixed effects & & & \\
\hline $\mathrm{N}$ & & & \\
\hline Adjusted $R^{2}$ & & & \\
\hline
\end{tabular}

Note: This table summarizes regression results from estimating Equation 4. The sample consists of 2,720 CEO-year observations for the period between 2002 and 2006. The dependent variable is Ownership. Ownership is defined as the natural logarithm of the sum of the proportion of shares outstanding plus the proportion of shares outstanding in options times the Black-Scholes delta hedge ratio. Size is natural logarithm of total market value where market value 
is the product of total common shares outstanding and the market price at fiscal year end. Size squared is square of Size. Stock return volatility is the annualized standard deviation of stock returns estimated over the 60 months prior to the beginning of the fiscal year. Stock return volatility squared is square of Stock return volatility. PPE is the ratio of plant, property and equipment to total assets. $R \& D$ and Advertising is the ratio of the sum of research and development expenses and advertising expenses to total assets. Cash flow is the ratio of operating cash flows to total assets. MTB is the ratio of total market value to total assets. Leverage is total debts divided by total assets. $t$-statistics are robust to heteroskedasticity and in the last column. Coefficients of the intercept, year indicators, and industry indicators are not shown. All variables are winsorized at the top and bottom percentiles. Statistical significance at the $10 \%, 5 \%$ and $1 \%$ levels is denoted by $* * *$ and $* * *$, respectively.

Table 1 summarizes regression results from estimating Equation 4, which indicate that the ownership model for CEO Ownership is statistically significant $(p<0.0001)$, with adjusted $R^{2}$ of 39.15 percent. All of the $t$-statistics are robust to heteroskedasticity and two-tailed. The log of the CEO Ownership is negatively related to firm size but positively related to firm size squared. These results are consistent with my expectation and the findings in Himmelberg, Hubbard and Palia (1999, p.369, Table 4, columns 1 and 2). I also find a concave relation between log of CEO Ownership and stock return volatility. The log of CEO Ownership is positively and significantly associated with stock return volatility but significantly and negatively related to stock return volatility squared. The results are consistent with the results reported in Table 3, page 328 in Core and Larcker (2002). PPE, R\&D Advertising expenses, Cash Flow, MTB coefficients have expected signs but are insignificant. $R \& D$ and Advertising expenses and $P P E$ variables are also insignificant in most of the estimations in Himmelberg, Hubbard and Palia (1999). Overall, the optimal ownership regression model provides consistent results with prior research. 


\subsection{Descriptive Statistics}

Panels A and B of Table 2 reports the descriptive statistics of the ownership and ownership determinants for 544 unique firms (247 unique dividend payers and 297 unique nondividend payers) between the sample period from 2002 to 2006. Dividend payers are larger (natural logarithm of the firm market value is 8.11) than non-dividend payers (natural logarithm of the firm market value is 7.09), $p$-value of the difference is 0.05 . Non-dividend payers have significantly higher stock return volatility and risky investment (measured by $R \& D$ and Advertising expenses) than dividend payers. Dividend payers tend to invest more in fixed assets ( $P P E$ investment on average is 27 percent of total assets) than non-dividend payers ( $P P E$ investment on average is 19 percent of total assets). Dividend payers also have higher cash flows than non-dividend payers. Cash flows account for 11 percent of total assets of dividend payers while in non-dividend payers cash flows only account for 9 percent of total assets. Overall, according to the prediction of the optimal ownership model, the differences in firm characteristics of dividend payers and non-dividend payers suggest that dividend payers are expected to have lower CEO ownership than non-dividend payers. Being consistent with this expectation, on average, CEOs of dividend payers hold 9.50 percent of their firms while CEOs in non-dividend payers hold 15.28 percent of their firms ( $p$-value of the difference is $<0.001$ ). The expected ownership level of dividend payers is 8.16 percent lower than the expected ownership level of non-dividend payers (18.82 percent). Over the sample period, CEOs of dividend payers over-owned their firms by 1.34 percent while CEOs of non-dividend payers under-owned their firms by 3.54 percent.

Panel C (D) of Table 2 presents the descriptive statistics of dividend payers in More (Less) Optimal subsample, respectively. Compared to CEOs in Less Optimal subsample, CEOs 
in More Optimal subsample have significantly lower actual ownership (4.39 percent compared to 14.41 percent) and the difference is significantly difference from zero at 1 percent level. The expected ownership of CEOs of More Optimal subsample is 7.17 percent and that of the Less Optimal subsample is 9.15 percent. However, the difference of the expected ownership is insignificant ( $p$-value is 0.27). The Deviation from optimal ownership of CEOs in More Optimal subsample is -2.58 percent while that in Less Optimal subsample is 5.26 percent. It suggests that on average, CEOs in More Optimal subsample under-owned their firms while CEOs in Less Optimal subsample over-owned their firms. The result from the test of the difference in ownership Deviation shows that CEOs in Less Optimal subsample deviated significantly further away from optimal ownership levels than those in More Optimal subsample. Other firm-level characteristics such as Stock return volatility, PPE, $R \& D$ and advertising, Cash flow, MTB and Leverage of firms in More and Less Optimal subsamples are similar and statistically insignificantly different. 
Table 2: Descriptive Statistics

\begin{tabular}{|c|c|c|c|c|c|}
\hline \multicolumn{6}{|c|}{ Panel A: Dividend Payer Total Sample $(N=1,235)$} \\
\hline & Mean & Std. Dev & Q1 & Median & Q3 \\
\hline Ownership & $9.50 \%$ & $35.29 \%$ & $2.24 \%$ & $10.13 \%$ & $39.85 \%$ \\
\hline Size & 8.11 & 1.60 & 6.81 & 8.06 & 9.38 \\
\hline Stock return volatility & 0.37 & 0.14 & 0.28 & 0.33 & 0.43 \\
\hline$P P E$ & 0.27 & 0.15 & 0.16 & 0.24 & 0.35 \\
\hline$R \& D$ and advertising & 0.04 & 0.04 & 0.01 & 0.03 & 0.05 \\
\hline Cash flow & 0.11 & 0.06 & 0.07 & 0.10 & 0.14 \\
\hline$M T B$ & 1.11 & 0.74 & 0.59 & 0.87 & 1.39 \\
\hline Leverage & 0.22 & 0.14 & 0.12 & 0.22 & 0.31 \\
\hline Expected ownership & $8.16 \%$ & $19.25 \%$ & $3.30 \%$ & $9.05 \%$ & $17.73 \%$ \\
\hline Deviation & $1.34 \%$ & $16.04 \%$ & $-1.06 \%$ & $2.08 \%$ & $22.12 \%$ \\
\hline \multicolumn{6}{|c|}{ Panel B: Non-dividend Payer Total Sample $(N=1,485)$} \\
\hline Ownership & $15.28 \%$ & $19.59 \%$ & $5.03 \%$ & $26.71 \%$ & $44.93 \%$ \\
\hline Size & 7.09 & 1.40 & 6.14 & 6.97 & 7.98 \\
\hline Stock return volatility & 0.60 & 0.22 & 0.43 & 0.58 & 0.76 \\
\hline$P P E$ & 0.19 & 0.15 & 0.08 & 0.14 & 0.27 \\
\hline$R \& D$ and advertising & 0.08 & 0.06 & 0.03 & 0.07 & 0.12 \\
\hline Cash flow & 0.09 & 0.08 & 0.04 & 0.09 & 0.15 \\
\hline$M T B$ & 0.93 & 0.69 & 0.45 & 0.73 & 1.16 \\
\hline Leverage & 0.16 & 0.16 & 0.02 & 0.13 & 0.28 \\
\hline Expected ownership & $18.82 \%$ & $39.06 \%$ & $10.65 \%$ & $20.19 \%$ & $37.16 \%$ \\
\hline Deviation & $-3.54 \%$ & $19.74 \%$ & $-5.62 \%$ & $6.52 \%$ & $7.77 \%$ \\
\hline \multicolumn{6}{|c|}{ Panel C: Dividend Payer - More Optimal Subsample $(N=570)$} \\
\hline & Mean & Std. Dev & Q1 & Median & Q3 \\
\hline Ownership & $4.39 \%$ & $18.26 \%$ & $1.37 \%$ & $3.88 \%$ & $15.26 \%$ \\
\hline Size & 8.46 & 1.64 & 7.20 & 8.61 & 9.85 \\
\hline Stock return volatility & 0.37 & 0.14 & 0.27 & 0.33 & 0.42 \\
\hline$P P E$ & 0.29 & 0.15 & 0.16 & 0.25 & 0.39 \\
\hline$R \& D$ and advertising & 0.04 & 0.04 & 0.01 & 0.03 & 0.05 \\
\hline Cash flow & 0.11 & 0.06 & 0.07 & 0.11 & 0.15 \\
\hline$M T B$ & 1.04 & 0.71 & 0.56 & 0.82 & 1.26 \\
\hline Leverage & 0.22 & 0.14 & 0.12 & 0.21 & 0.31 \\
\hline Expected ownership & $7.17 \%$ & $26.48 \%$ & $2.57 \%$ & $5.45 \%$ & $13.81 \%$ \\
\hline Deviation & $-2.58 \%$ & $-8.22 \%$ & $-1.20 \%$ & $-1.57 \%$ & $1.45 \%$ \\
\hline \multicolumn{6}{|c|}{ Panel D: Dividend Payer - Less Optimal Subsample $(N=665)$} \\
\hline & Mean & Std. Dev & Q1 & Median & Q3 \\
\hline Ownership & $14.41 \%$ & $38.67 \%$ & $4.88 \%$ & $19.59 \%$ & $78.66 \%$ \\
\hline Size & 7.82 & 1.49 & 6.64 & 7.78 & 8.89 \\
\hline Stock return volatility & 0.37 & 0.14 & 0.28 & 0.34 & 0.44 \\
\hline$P P E$ & 0.26 & 0.14 & 0.15 & 0.24 & 0.33 \\
\hline$R \& D$ and Advertising & 0.04 & 0.04 & 0.01 & 0.02 & 0.04 \\
\hline Cash flow & 0.10 & 0.06 & 0.06 & 0.10 & 0.13 \\
\hline$M T B$ & 1.17 & 0.76 & 0.62 & 0.94 & 1.48 \\
\hline Leverage & 0.22 & 0.15 & 0.12 & 0.22 & 0.32 \\
\hline Expected ownership & $9.15 \%$ & $17.40 \%$ & $4.88 \%$ & $10.97 \%$ & $21.44 \%$ \\
\hline Deviation & $5.26 \%$ & $21.27 \%$ & $-0.00 \%$ & $8.62 \%$ & $57.22 \%$ \\
\hline
\end{tabular}


Note: This table presents descriptive statistics for a balanced sample of 1,235 CEO-year observations from 247 unique dividend payers and a sample of 1,485 CEO-year observations from 297 unique non-dividend payers between the period 2002 and 2006. Panel $A(B)$ presents CEO ownership and firm descriptive statistics of the dividend (non-dividend) payer sample. Panel $C(D)$ presents the CEO ownership and firm descriptive statistics of the More (Less) Optimal subsample. Ownership is defined as the natural logarithm of the sum of the proportion of shares outstanding plus the proportion of shares outstanding in options times the Black-Scholes delta hedge ratio. Size is natural logarithm of total market value where market value is the product of total common shares outstanding and the market price at fiscal year end. Stock return volatility is the annualized standard deviation of stock returns estimated over the 60 months prior to the beginning of the fiscal year. PPE is the ratio of plant, property and equipment to total assets. $R \& D$ and Advertising is the ratio of the sum of research and development expenses and advertising expenses to total assets. Cash flow is the ratio of operating cash flows to total assets. MTB is the ratio of total market value to total assets. Leverage is total debts divided by total assets. Expected ownership is the expected value of the ownership dependent variable obtained from the regression results of Equation 4, then converted into percentage. Deviation is the residuals obtained from the regression results of Equation 4, then converted into percentage. I use the difference in absolute value of Deviation in 2002 and that in 2004 to separate the 247 dividend payers into two subsamples: More Optimal (114 CEOs) and Less Optimal (133 CEOs). CEOs belong to More Optimal subsample if the absolute value of Deviation in 2002 is greater than the absolute value of Deviation in 2004. CEOs belong to Less Optimal subsample if the absolute value of Deviation in 2002 is less than the absolute value of Deviation in 2004.

\subsection{Change in CEO Ownership around the 2003 Dividend Tax Cut}

The univariate results presented in Figure 1 and Table 3 are consistent with Hypothesis 1.

Figure 1 presents the actual and expected levels of Ownership of CEOs of dividend payers (the

lower two lines) and non-dividend payers (the upper two lines) of the sample for the period between 2002 and 2006. The solid lines present the actual ownership levels and the dotted lines present the expected (optimal) ownership levels. The expected ownership is the expected value of the dependent variable Ownership obtained from the regression results of Equation 4, then converted into percentage. The distance between the actual ownership and expected ownership levels is ownership Deviation.

The percentage of actual and expected Ownership of CEOs from non-dividend payers is significantly greater than that of CEOs from dividend payers at 5 percent level for all the years in my sample period. Such finding is expected because the size of dividend payers is significantly larger than that of non-dividend payers and as firm size increases, the actual ownership 
percentage tends to decrease because a similar portion of ownership mechanically becomes more expensive to hold (Demsetz and Lehn 1985).

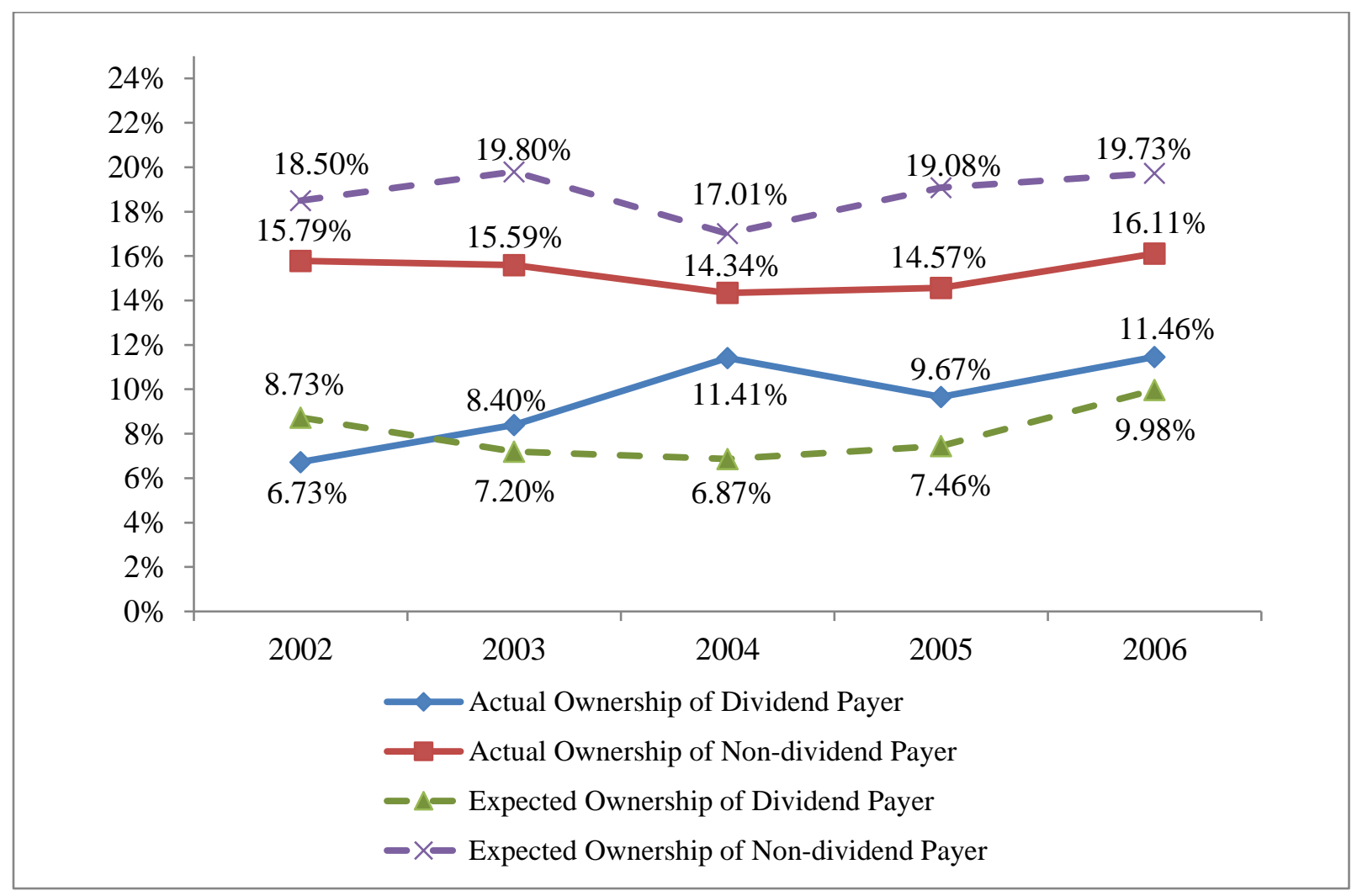

Figure 1: CEO Actual and Expected Ownership between 2002 and 2006

Note: This figure presents the actual and expected Ownership of CEOs in 247 unique dividend payers and 297 nondividend payers in the sample in the period between 2002 and 2006. Ownership is defined as the natural logarithm of the sum of the proportion of shares outstanding plus the proportion of shares outstanding in options times the Black-Scholes delta hedge ratio. Expected ownership is the expected value of the ownership dependent variable obtained from the regression results of Equation 4, then converted into percentage.

There is a significant increase in the actual ownership of CEO from dividend payers after the 2003 DTC. On average, CEOs in dividend payers held 6.73 percent of their firms in 2002 and 11.41 percent of their firms in 2004. The increase of 4.68 percent ownership is significant at 1 percent level. In contrast, the actual ownership level of CEO from non-dividend payers reduced by 1.45 percent (15.79 percent actual ownership in 2002 and 14.34 percent actual ownership in 2004) and this change is insignificantly different from zero. The results support my first 
hypothesis that the 2003 DTC had a positive impact on CEO ownership of dividend payers. I also examined the change in CEO ownership using median values and obtained similar results. The results are untabulated for the sake of brevity.

For non-dividend payers, the ownership Deviation was rather stable between 2002 and 2004. The Deviation was 2.71 percent in 2002 (18.50 percent actual ownership and 15.79 percent expected ownership) and 2.67 percent in 2004 (17.01 percent actual ownership and 14.34 percent expected ownership). In contrary, the ownership Deviation of CEOs in dividend payers significantly widened from 2.00 percent in 2002 (8.73 percent actual ownership and 6.73 percent expected ownership) to 4.54 percent in 2004 (11.41 percent actual ownership and 6.87 percent expected ownership). The increase in Deviation of dividend payers between 2002 and 2004 suggests that the increase in actual ownership from 6.73 percent in 2002 to 11.41 percent in 2004 is suboptimal. On average, CEOs of dividend payers had moved from under-owning their firms to over-owning their firms. According to the prediction of the optimal ownership model, suboptimal ownership is associated with poorer firm performance.

To provide more insight about the change in actual and expected ownership of dividend payers around the 2003 DTC, I separate 247 dividend payers into two subsamples based on the change in Deviation from optimal ownership level between 2002 and 2004: 114 More Optimal and 133 Less Optimal firms. Firms belong to More (Less) Optimal subsample if the absolute values of Deviation from 2002 is greater (less) than the absolute value of Deviation in 2004. 


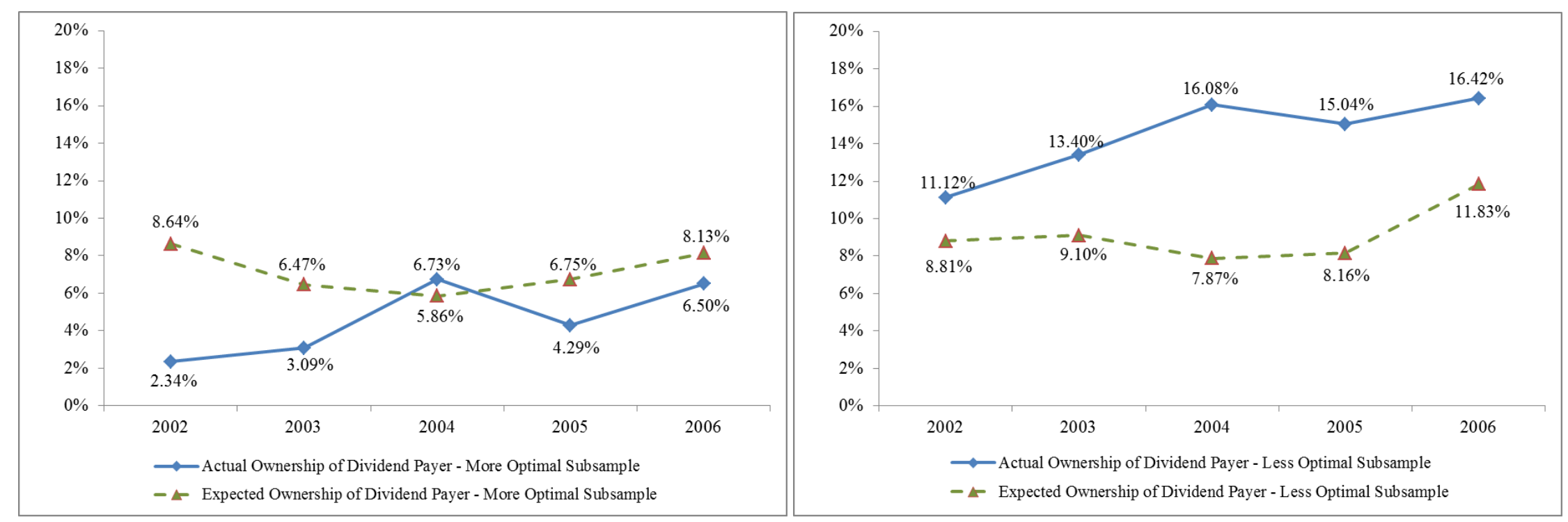

Figure 2: CEO Actual and Expected Ownership of Dividend Payer in More and Less Optimal Subsamples between 2002 and 2006

Note: This figure presents the actual and expected Ownership of CEOs in 114 unique dividend payers in More Optimal subsample and 133 unique dividend payers in Less Optimal subsample in the period between 2002 and 2006. Ownership is defined as the natural logarithm of the sum of the proportion of shares outstanding plus the proportion of shares outstanding in options times the Black-Scholes delta hedge ratio. Expected ownership is the expected value of the ownership dependent variable obtained from the regression results of Equation 4, then converted into percentage. Deviation is the residuals obtained from the regression results of Equation 4, then converted into percentage. I use the difference in absolute value of Deviation in 2002 and that in 2004 to separate the 247 dividend payers into two subsamples: More Optimal (114 CEOs) and Less Optimal (133 CEOs). CEOs belong to More Optimal subsample if the absolute value of Deviation in 2002 is greater than the absolute value of Deviation in 2004. CEOs belong to Less Optimal subsample if the absolute value of Deviation in 2002 is less than the absolute value of Deviation in 2004. 
Figure 2 presents the actual and expected ownership of dividend payers in More Optimal subsample (the left chart) and Less Optimal subsample (the right chart). The solid lines present the actual ownership level and the dotted lines present the expected ownership level estimated from regression specified in Equation 4. The actual ownership levels of CEOs increased significantly between 2002 and 2004 for both More and Less Optimal subsamples ( $p$-values are 0.01). The level of actual ownership of CEOs in dividend payers in More Optimal subsample increased from 2.34 percent in 2002 to 6.73 percent in 2004. And the level of actual ownership of CEOs in dividend payers in Less Optimal subsample increased from 11.12 percent in 2002 to 16.08 percent in 2004. It is worth to note that although the actual ownership levels of CEOs in More and Less Optimal subsamples are significantly different at 5 percent level, the expected ownership levels of CEOs in these two subsamples are not significantly different during the period between 2002 and 2006.

CEOs in More Optimal subsample under-owned their firms in 2002, 2003, 2005 and 2006 and slightly over-owned their firms in 2004. The 2003 DTC impact had move the actual ownership of CEOs in More Optimal subsample closer to the optimal levels. Ownership Deviation significantly narrowed from 6.30 percent in 2002 (the difference between 8.64 percent actual ownership and 2.34 percent expected ownership) to 0.87 percent in 2004 (the difference between 6.73 percent actual ownership and 5.86 percent expected ownership) with $p$-value of the change is 0.001 . The increase in actual ownership of CEOs in More Optimal subsample after the 2003 DTC had moved these CEOs from a less optimal position to a more optimal ownership position. According to the prediction of the optimal ownership model, More Optimal subsample firms should experience an improvement in firm performance after the 2003 DTC. 
On the other hand, CEOs in Less Optimal subsample over-owned their firms from 2002 to 2006. By holding more equity in their firms after the 2003 DTC, CEOs in the Less Optimal subsample deviated further away from the optimal ownership levels. The ownership Deviation significantly increased by almost 4 times. The ownership Deviation was 2.31 percent in 2002 (the difference between 11.12 percent actual ownership and 8.81 percent expected ownership) and was 8.21 percent in 2004 (the difference between 16.08 percent actual ownership and 7.87 percent expected ownership) with $p$-value of the change is 0.001 . According to the prediction of the optimal ownership model, Less Optimal subsample firms should experience poorer performance after the 2003 DTC. 


\section{Table 3: Change in Actual CEO Ownership and CEO Ownership Deviation from Optimal Levels between 2002 and 2004}

\begin{tabular}{|c|c|c|c|c|}
\hline \multicolumn{5}{|c|}{ Panel A: Comparison of Change in CEO ownership between Dividend Payers and Non-dividend Payers } \\
\hline Actual CEO Ownership & 2002 & 2004 & $(2004-2002)$ & $\begin{array}{c}p \text {-value } \\
(2004-2002)\end{array}$ \\
\hline $\begin{array}{l}\text { Dividend Payer } \\
(\mathrm{N}=247)\end{array}$ & $6.73 \%$ & $11.41 \%$ & $4.68 \%$ & 0.01 \\
\hline $\begin{array}{l}\text { Non-dividend Payer } \\
(\mathrm{N}=297)\end{array}$ & $15.79 \%$ & $14.34 \%$ & $-1.45 \%$ & 0.21 \\
\hline \multicolumn{3}{|c|}{ Difference in differences } & $6.13 \%$ & 0.001 \\
\hline $\begin{array}{l}\text { CEO Ownership Deviation } \\
\text { From Optimal Level }\end{array}$ & 2002 & 2004 & $\begin{array}{l}\text { Absolute value } \\
(2004-2002)\end{array}$ & $\begin{array}{c}p \text {-value } \\
(2004-2002)\end{array}$ \\
\hline $\begin{array}{l}\text { Dividend Payer } \\
(\mathrm{N}=247)\end{array}$ & $-2.00 \%$ & $4.54 \%$ & $2.54 \%$ & 0.06 \\
\hline $\begin{array}{l}\text { Non-dividend Payer } \\
(\mathrm{N}=297)\end{array}$ & $-2.71 \%$ & $-2.67 \%$ & $0.04 \%$ & 0.87 \\
\hline \multicolumn{3}{|c|}{ Difference in differences } & $2.50 \%$ & 0.08 \\
\hline \multicolumn{5}{|c|}{$\begin{array}{l}\text { Panel B: Comparison of Change in CEO ownership between Dividend Payers More and Less Optimal } \\
\text { Subsamples }\end{array}$} \\
\hline Actual CEO Ownership & 2002 & 2004 & $(2004-2002)$ & $\begin{array}{c}p \text {-value } \\
(2004-2002)\end{array}$ \\
\hline $\begin{array}{l}\text { More Optimal Subsample } \\
(\mathrm{N}=114)\end{array}$ & $2.34 \%$ & $6.73 \%$ & $4.39 \%$ & 0.01 \\
\hline $\begin{array}{l}\text { Less Optimal Subsample } \\
(\mathrm{N}=133)\end{array}$ & $11.12 \%$ & $16.08 \%$ & $4.96 \%$ & 0.01 \\
\hline \multicolumn{3}{|c|}{ Difference in differences } & $-0.57 \%$ & 0.89 \\
\hline $\begin{array}{l}\text { CEO Ownership Deviation } \\
\text { From Optimal Level }\end{array}$ & 2002 & 2004 & $\begin{array}{l}\text { Absolute value } \\
(2004-2002)\end{array}$ & $\begin{array}{c}p \text {-value } \\
(2004-2002)\end{array}$ \\
\hline $\begin{array}{l}\text { More Optimal Subsample } \\
(\mathrm{N}=114)\end{array}$ & $-6.30 \%$ & $0.87 \%$ & $-5.43 \%$ & 0.001 \\
\hline $\begin{array}{l}\text { Less Optimal Subsample } \\
(\mathrm{N}=133)\end{array}$ & $2.31 \%$ & $8.21 \%$ & $5.90 \%$ & 0.001 \\
\hline \multicolumn{3}{|c|}{ Difference in differences } & $11.33 \%$ & $<0.001$ \\
\hline
\end{tabular}

Note: This table reports the means of actual CEO Ownership and CEO Ownership Deviation from optimal levels of 247 Dividend Payers and 297 non-dividend payers in Panel A and of dividend payers in More and Less Optimal Subsamples in Panel B for the years 2002 and 2004 (one year pre and post the DTC event). Actual CEO Ownership is defined as the sum of the proportion of shares outstanding plus the proportion of shares outstanding in options times the Black-Scholes delta hedge ratio. Expected ownership is the expected value of the ownership dependent variable obtained from the regression results of Equation 4, then converted into percentage. CEO Ownership Deviation is the residuals obtained from the regression results of Equation 4, then converted into percentage. I use the difference in absolute value of Deviation in 2002 and that in 2004 to separate the 247 dividend payers into two subsamples: More Optimal (114 CEOs) and Less Optimal (133 CEOs). CEOs belong to More Optimal subsample if the absolute value of Deviation in 2002 is greater than the absolute value of Deviation in 2004. CEOs belong to Less Optimal subsample if the absolute value of Deviation in 2002 is less than the absolute value of Deviation in 2004. 
Overall, the 2003 DTC had a significant impact on CEO ownership of dividend payers in both More and Less Optimal subsamples but did not have impact of CEO ownership of nondividend payers. The results are consistent with the prediction of the first hypothesis. The expansion in ownership Deviation in 247 dividend payers after the 2003 DTC was driven by 133 dividend payers in the Less Optimal subsample, not by the 114 dividend payers in the More Optimal subsample.

\subsection{Channels for the Change in CEO Ownership}

The change in CEO ownership generally comes from four channels:

(1) new restricted stock grants;

(2) new stock option grants;

(3) vested option exercises by CEOs; and

(4) CEO trading in open-market including share sales and purchases.

The changes through the first two channels are fulfilled by the board of directors while the changes through the last two channels are accomplished by the CEOs themselves. ${ }^{9}$ To provide more insights about how CEO ownership increased after the 2003 DTC, I examine changes in CEO ownership associated with each of these four channels.

Execucomp database provides data about equity ownership including vested and unvested shares and options held directly by CEOs and annual compensation data including restricted stock and stock option grants. To examine the change in CEO ownership from the first, second and third channels, I use annual compensation and option exercise data from Execucomp

\footnotetext{
${ }^{9}$ Change in total number of shares owned from 2002 to $2004=$ Number of restricted shares granted in 2002 and 2004 + Number of vested option exercised in 2002 and 2004 + Open market purchases in 2002 and 2004 - Open market sales in 2002 and 2004.
} 
database. For the last channel, since Execucomp does not provide data of CEO's trading in open market, I examine the change in total number of shares owned between 2002 and 2004 to indirectly estimate the net impact of open market sales/purchases on CEO ownership. I examine the changes of new restricted stock grants, new stock option grants, vested option exercises and total number of shares owned between 2002 and 2004 using difference in difference approach with non-dividend payers as control group. The difference in difference approach controls for the impact of time-invariant firm characteristics and temporal trend in CEO compensation (Murphy 1999).

I measure the change in restricted stock grants and stock option grants in two different ways: (1) as the change in dollar value; and (2) as the change in percentage of total compensation. In Table 4, Panels A and C report the changes in dollar value and Panels B and D report the changes as percentage of total compensation. 
Table 4: Changes in CEO Ownership through New Stock and New Option Grants

\begin{tabular}{|c|c|c|c|c|c|c|}
\hline & $\begin{array}{l}\text { Stock Grant } \\
2002\end{array}$ & $\begin{array}{l}\text { Stock Grant } \\
2004\end{array}$ & $\begin{array}{c}\Delta \text { Annual Stock Grant } \\
(2004-2002)\end{array}$ & $\begin{array}{c}\text { Option Grant } \\
2002\end{array}$ & $\begin{array}{l}\text { Option Grant } \\
2004\end{array}$ & $\begin{array}{c}\Delta \text { Annual Option Grant } \\
(2004-2002)\end{array}$ \\
\hline $\begin{array}{l}\text { Dividend Payers }(1) \\
(\mathrm{N}=247)\end{array}$ & $\$ 812,912$ & $\$ 1,230,650$ & $\$ 417,738 * * *$ & $\$ 3,035,090$ & $\$ 2,281,410$ & $-\$ 753,680 * * *$ \\
\hline $\begin{array}{l}\text { Non-dividend Payers (2) } \\
(\mathrm{N}=297)\end{array}$ & $\$ 388,165$ & $\$ 225,263$ & $-\$ 162,902$ & $\$ 2,758,200$ & $\$ 2,846,020$ & $\$ 87,820$ \\
\hline $\begin{array}{l}\text { Difference in differences } \\
(1)-(2)\end{array}$ & & & $\$ 580,640 * * *$ & & & $-\$ 841,500 * * *$ \\
\hline
\end{tabular}

Panel B: Comparison between Dividend Payers and Non-dividend Payers: Annual Equity Grants at Percentage of Total Compensation

\begin{tabular}{|c|c|c|c|c|c|c|}
\hline & $\begin{array}{l}\text { Stock Grant } \\
2002\end{array}$ & $\begin{array}{l}\text { Stock Grant } \\
2004\end{array}$ & $\begin{array}{c}\Delta \text { Annual Stock Grants } \\
(2004-2002)\end{array}$ & $\begin{array}{l}\text { Option Grant } \\
2002\end{array}$ & $\begin{array}{l}\text { Option Grant } \\
2004\end{array}$ & $\begin{array}{c}\Delta \text { Annual Option Grant } \\
(2004-2002)\end{array}$ \\
\hline $\begin{array}{l}\text { Dividend Payers }(1) \\
(\mathrm{N}=247)\end{array}$ & $8.307 \%$ & $12.382 \%$ & $4.080 \% * * *$ & $40.389 \%$ & $29.165 \%$ & $-11.220 \% * * *$ \\
\hline $\begin{array}{l}\text { Non-dividend Payers (2) } \\
(\mathrm{N}=297)\end{array}$ & $21.608 \%$ & $4.273 \%$ & $-17.340 \% * * *$ & $51.572 \%$ & $44.782 \%$ & $-6.790 \% * * *$ \\
\hline $\begin{array}{l}\text { Difference in differences } \\
\text { (1) - (2) }\end{array}$ & & & $21.410 \% * * *$ & & & $-4.430 \% * * *$ \\
\hline
\end{tabular}

Panel C: Comparison between Dividend Payers in More and Less Optimal Subsamples: Annual Equity Grants at Dollar Value

\begin{tabular}{|c|c|c|c|c|c|c|}
\hline & $\begin{array}{l}\text { Stock Grant } \\
2002\end{array}$ & $\begin{array}{l}\text { Stock Grant } \\
2004\end{array}$ & $\begin{array}{c}\Delta \text { Annual Stock Grant } \\
(2004-2002)\end{array}$ & $\begin{array}{l}\text { Option Grant } \\
2002\end{array}$ & $\begin{array}{l}\text { Option Grant } \\
2004\end{array}$ & $\begin{array}{c}\Delta \text { Annual Option Grant } \\
(2004-2002)\end{array}$ \\
\hline $\begin{array}{l}\text { More Optimal (1) } \\
(\mathrm{N}=114)\end{array}$ & $\$ 745,137$ & $\$ 1,014,440$ & $\$ 269,303^{*}$ & $\$ 3,869,800$ & $\$ 1,809,770$ & $-\$ 2,060,030 * * *$ \\
\hline $\begin{array}{l}\text { Less Optimal (2) } \\
(\mathrm{N}=133)\end{array}$ & $\$ 871,006$ & $\$ 1,402,880$ & $\$ 531,874 * *$ & $\$ 2,873,460$ & $\$ 2,319,560$ & $-\$ 553,900 *$ \\
\hline $\begin{array}{c}\text { Difference in differences } \\
\text { (1) - (2) }\end{array}$ & & & $-\$ 262,571$ & & & $-\$ 1,506,130 * * *$ \\
\hline
\end{tabular}

Panel D: Comparison between Dividend Payers in More and Less Optimal Subsamples: Annual Equity Grants at Percentage of Total Compensation

\begin{tabular}{|c|c|c|c|c|c|c|}
\hline & $\begin{array}{l}\text { Stock Grant } \\
2002\end{array}$ & $\begin{array}{l}\text { Stock Grant } \\
2004\end{array}$ & $\begin{array}{c}\Delta \text { Annual Stock Grant } \\
(2004-2002)\end{array}$ & $\begin{array}{l}\text { Option Grant } \\
2002\end{array}$ & $\begin{array}{l}\text { Option Grant } \\
2004\end{array}$ & $\begin{array}{c}\Delta \text { Annual Option Grant } \\
(2004-2002)\end{array}$ \\
\hline $\begin{array}{l}\text { More Optimal (1) } \\
(\mathrm{N}=114)\end{array}$ & $8.084 \%$ & $10.140 \%$ & $2.060 \% *$ & $36.812 \%$ & $25.389 \%$ & $-11.420 \% * * *$ \\
\hline $\begin{array}{l}\text { Less Optimal } \\
(\mathrm{N}=133)\end{array}$ & $9.016 \%$ & $14.168 \%$ & $5.150 \% * *$ & $44.593 \%$ & $33.906 \%$ & $-10.690 \% * * *$ \\
\hline $\begin{array}{l}\text { Difference in differences } \\
(1)-(2)\end{array}$ & & & $-3.100 \%$ & & & $-0.740 \%$ \\
\hline
\end{tabular}


Note: Panel $A(B)$ of this table presents the mean difference in CEO annual equity grants in year 2002 and 2004 for 247 dividend payers and 297 non-dividend payers in dollar value (percentage of total compensation). Panel $C(D)$ of this table present the mean difference in CEO annual equity grants of 114 dividend payers in More Optimal subsample and 133 dividend payers in Less Optimal subsample. CEO Ownership Deviation is the residuals obtained from the regression results of Equation 4, then converted into percentage. I use the difference in absolute value of Deviation in 2002 and that in 2004 to separate the 247 dividend payers into two subsamples: More Optimal (114 CEOs) and Less Optimal (133 CEOs). CEOs belong to More Optimal subsample if the absolute value of Deviation in 2002 is greater than the absolute value of Deviation in 2004. CEOs belong to Less Optimal subsample if the absolute value of Deviation in 2002 is less than the absolute value of Deviation in 2004. Non-dividend payers are used as controls. $*, * *, * * *$ indicates significance at $10 \%, 5 \%$ and $1 \%$ confidence levels, respectively.

Panel A of Table 4 presents the change in restricted stock grants and stock option grants of CEOs in dividend payers and non-dividend payers at dollar value and Panel B presents such changes in percentages of total compensation. Overall, the results suggest that dividend payers substitute stock option grants by restricted stock grants. On average, restricted stock grants of CEOs in dividend payers increased significantly by $\$ 417,738$ from 2002 to 2004. Stock option grants of CEOs in dividend payers reduced significantly by $\$ 753,680$. Both restricted stocks and stock options are considered equity-based compensation. However, the expected values of restricted stocks and stock options differ significantly regarding changes in dividend. Dividend payments increase the expected value of restricted stocks but reduce the expected value of stock options. The favorable tax treatment of the 2003 DTC induced dividend payers to re-design the annual compensation package to their CEOs by increasing more restricted stock grants and reducing stock option grants. The changes in annual restricted stock grants and stock option grants between 2002 and 2004 of dividend payers are significant at 5 percent level. Compared with non-dividend payers, dividend payers rewarded significantly more restricted stocks and fewer stock option grants. The differences in the changes of restricted stock grants between dividend payers and non-dividend payers are $\$ 580,640$ in dollar amount and 21.41 percent as percentage of total compensation, respectively. Compared to non-dividend payers, dividend payers reduced stock options grant value by $\$ 841,500$ and the reduction is equivalent to 4.43 percent of total compensation. 
Panels $\mathrm{C}$ and D of Table 4 present the mean differences of annual restricted stock and stock option grants of CEOs of dividend payers in More and Less Optimal subsamples. Overall, the results suggest that dividend payers in both subsamples follow similar compensation policy by increasing restricted stock grants and reducing stock option grants. Dividend payers in the More Optimal subsample reduced the option grants in their CEO annual compensation package by $\$ 2,060,030$ (11.42\% of total compensation) while dividend payers in the Less Optimal subsample reduced the options grants in their CEO annual compensation package by $\$ 553,900$ (10.69\% of total compensation).

To test for the change in CEO Ownership through the last two channels (net of openmarket trading and stock option exercises), I adopt the difference-in-difference approach. I compute the change in total shares held by CEOs in dividend payers from 2002 to 2004. This change controls for the impact of time-invariant factors on CEO stock holdings. I then compare this change to the change in the total shares held by CEOs in non-dividend payers over the same period. Using non-dividend payers as a control is to control for the temporal trend in CEO share holdings. Next, I compare the change in the total number of options exercised from 2002 to 2004 of dividend payers and non-dividend payers. 
Table 5: Changes in CEO Ownership through Option Exercises and Open-market Trading Activities

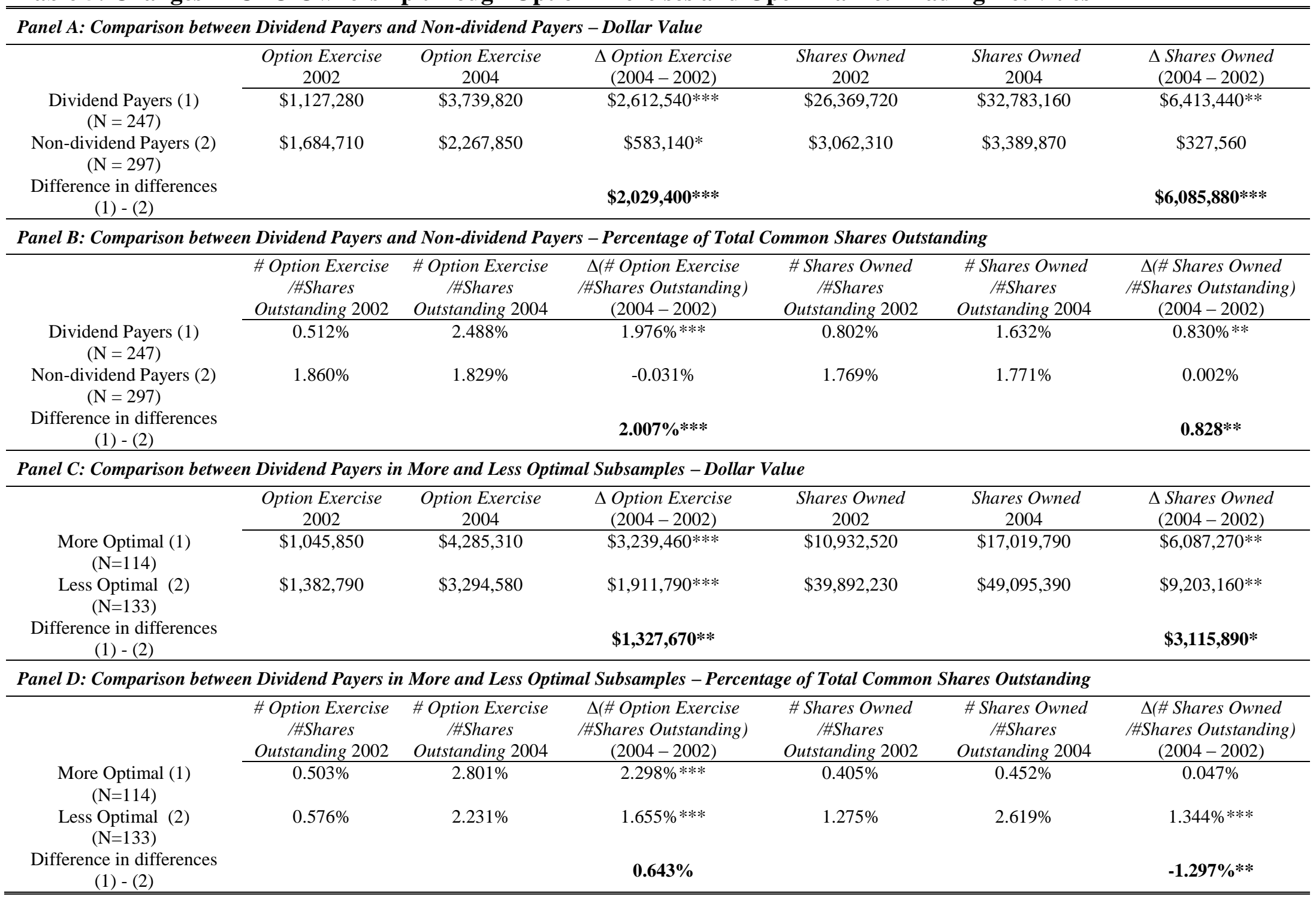


Note: This table presents descriptive statistics about CEO total shares holdings and total number of option exercised during the fiscal year in 2002 and 2004 for 247 dividend payers and 297 non-dividend payers. Total Shares Owned is total shares owned as reported in Execucomp database. Number of stock option exercised is the total number of options exercised by the CEO during the year as reported in Execucomp database. *, **, *** indicates significance at $10 \%, 5 \%$ and $1 \%$ confidence levels, respectively.

The results reported in Panels A and B of Table 5 indicate that the value of options exercised by CEOs in dividend payers between 2002 and 2004 significantly increased by $\$ 2,612,540$. In 2002, the total value of option exercised by CEOs of dividend payers accounts for $0.512 \%$ of their firms' total common shares outstanding. In 2004 , the value of option exercised of these CEOs increased to $2.488 \%$ of the value of their firms' total common shares outstanding. The value of total shares holdings of CEOs of dividend payers also increased by $\$ 6,413,440$. In 2002, the value of total shares held by CEOs of dividend payers accounts for $0.802 \%$ of the total common shares outstanding. In 2004, the value of total shares held by CEOs of dividend payers increased to $1.632 \%$. In contrast, CEOs of non-dividend payers do not change the proportion of option exercises or shares holdings between 2002 and 2004.

The comparison results between dividend payers' CEOs in the More and Less Optimal subsamples are presented in Panels $\mathrm{C}$ and D of Table 5. The value of options exercised by the CEOs in the More Optimal subsample is $\$ 1,327,760$ higher than that value of CEOs in the Less Optimal subsample. The change in the value of total shares holding of CEOs in the More Optimal subsample is $\$ 3,115,890$ lower than that value of CEOs in the Less Optimal subsample. My findings suggest that the 2003 DTC gave incentives to CEOs of dividend payers to exercise more options hold more stocks. The results are in contrast with the findings documented in Ofek and Yermack (2000) that executives negate the impact of stock-based compensation by selling previously owned shares when they are granted more restricted stocks and exercise options. 
In sum, I find consistent evidences supporting my first hypothesis that the 2003 DTC has a positive impact on CEO ownership of dividend payers. After the 2003 DTC, the average equity ownership of CEOs increased by 4.68 percent. The increase in CEO ownership is completed through higher restricted stock grants, higher number of stock options exercises and a positive net change in open market trading. 


\section{Changes CEO Ownership and their Impacts on R\&D Investment, Investment Efficiency and Firm Performance}

\subsection{Impact on R\&D Investment: Methodology and Results}

To test the second hypothesis that changes in CEO ownership is associated with changes in the level of risky investment, I use the difference-in-difference approach and examine the changes in $R \& D$ investment of dividend payers in the More and Less Optimal subsamples between 2002 and 2004 and 2002 and 2005, respectively. Since the change in CEO ownership is observed in 2004, I use the year 2004 and 2005 to investigate the changes in $R \& D$ investment decision to capture the current and one-year lag of the changes in investment decision of dividend payers. I first compute the five-year cumulative $R \& D$ investment assuming an annual depreciation rate of 20 percent as in Chan, Lakonishok and Sougiannis (2001) and Lev, Sarath, and Sougiannis (2005) for each year in the sample period using the following formula:

$$
R \& D_{i t}=R \& D_{i t}+0.8 \times R \& D_{i t-1}+0.6 \times R \& D_{i t-2}+0.4 \times R \& D_{i t-3}+0.2 \times R \& D_{i t-4}
$$

where $R \& D_{i t}$ denotes firm $i$ 's $R \& D$ expenditure in fiscal year $t$. Then, I regress the changes in $R \& D$ investment on the changes of CEO Ownership, Optimal dummy variable, an interaction term between CEO Ownership and Optimal dummy variable and other control variables using the following model:

$\Delta R \& D=\alpha_{0}+\alpha_{1} \Delta$ Ownership $+\alpha_{2}$ Optimal $+\alpha_{3} \Delta$ Ownership $\times$ Optimal $+\beta \Delta$ Controls $+\varepsilon$

where $\Delta$ Ownership is the difference between CEO Ownership in 2002 and 2004, Ownership is defined as the natural logarithm of the sum of the proportion of shares outstanding plus the proportion of shares outstanding in options times the Black-Scholes delta hedge ratio. Optimal is 
a dummy variable that takes the value of 1 if dividend payers belong to the More Optimal subsample and zero otherwise. Dividend payers belong to More Optimal if the difference in absolute value of Deviation in 2002 is greater than the absolute value of Deviation in 2004, where Deviation is the residuals obtained from the regression results of Equation 4. Size is natural logarithm of total market value where market value is the product of total common shares outstanding and the market price at fiscal year-end. $M T B$ is the ratio of total market value to total assets. Leverage is total debt divided by total assets. Stock return volatility is the annualized standard deviation of stock returns estimated over the 60 months prior to the beginning of the fiscal year. Cash flow is the net cash flow scaled by total assets. Capital expenditure is the total capital expenditure scaled by total assets. Working capital is total working capital scaled by total assets. I follow prior research (Coles, Daniel and Naveen 2006) to include Size, MTB, Leverage, Stock return volatility, Cash flow, Capital expenditure and Working capital expenditure as control variables in regression Equation (7). With this design, the sum of the two coefficients $\alpha_{1}$ and $\alpha_{3}$ represents the impact of changes in CEO ownership on changes in $R \& D$ investment of dividend payers in the More Optimal subsample, and the coefficient $\alpha_{1}$ represents the impact of changes in CEO ownership on changes in $R \& D$ investment of dividend payers in the Less Optimal subsample. The regression estimation results of Equation 7 are reported in Table 6. 
Table 6: Changes in CEO Ownership and R\&D Investment

$\Delta R \& D=\alpha_{0}+\alpha_{1} \Delta$ Ownership $+\alpha_{2}$ Optimal $+\alpha_{3} \Delta$ Ownership $\times$ Optimal $+\beta \Delta$ Controls $+\varepsilon$

\begin{tabular}{|c|c|c|c|c|}
\hline \multirow[b]{3}{*}{ Explanatory variable } & \multicolumn{2}{|c|}{ Panel A: Change from 2002 to 2004} & \multicolumn{2}{|c|}{ Panel B: Change from 2002 to 2005} \\
\hline & \multicolumn{2}{|c|}{$\Delta R \& D$} & \multicolumn{2}{|c|}{$\Delta R \& D$} \\
\hline & $\begin{array}{c}\text { Coefficient } \\
\text { Estimate }\end{array}$ & $p$-value & $\begin{array}{l}\text { Coefficient } \\
\text { Estimate }\end{array}$ & $p$-value \\
\hline Intercept & -0.0008 & 0.764 & -0.0015 & 0.633 \\
\hline$\Delta$ Ownership & -0.0025 & 0.001 & -0.0026 & 0.001 \\
\hline Optimal & 0.0060 & 0.032 & 0.0055 & 0.053 \\
\hline$\Delta$ Ownership $\times$ Optimal & 0.0020 & 0.024 & 0.0016 & 0.061 \\
\hline$\Delta$ Size & -0.0127 & $<0.0001$ & -0.0135 & $<0.0001$ \\
\hline$\triangle M T B$ & 0.0146 & $<0.0001$ & 0.0158 & $<0.0001$ \\
\hline$\Delta$ Leverage & 0.0051 & 0.760 & 0.0039 & 0.825 \\
\hline$\Delta$ Stock return volatility & 0.0556 & $<0.0001$ & 0.0620 & $<0.0001$ \\
\hline$\Delta$ Cash flow & -0.0281 & 0.665 & -0.0355 & 0.608 \\
\hline$\Delta$ Capital expenditure & -0.186 & $<0.0001$ & -0.2166 & $<0.0001$ \\
\hline$\Delta$ Working capital & 0.0042 & 0.012 & 0.0043 & 0.021 \\
\hline Industry fixed effects & \multicolumn{2}{|c|}{ Yes } & \multicolumn{2}{|c|}{ Yes } \\
\hline $\mathrm{N}$ & \multicolumn{2}{|c|}{247} & \multicolumn{2}{|c|}{247} \\
\hline Adjusted $\mathrm{R}^{2}$ & \multicolumn{2}{|c|}{$28.05 \%$} & \multicolumn{2}{|c|}{$28.00 \%$} \\
\hline
\end{tabular}

Note: This table presents the regression results of regressing $\Delta R \& D$ on $\Delta$ Ownership, Optimal ownership indicator variable and other control variables for 247 dividend payers. In Panel $\mathrm{A}$, the dependent variable, $\Delta R \& D$, is measured as the difference between 5-year accumulative $R \& D$ investments in 2002 and 2004 . In Panel $\mathrm{B}$, the dependent variable, $\Delta R \& D$, is measured as the difference between 5-year accumulative $R \& D$ investments in 2002 and 2005. The 5-year accumulative $R \& D$ investment of 2004 (2005) is computed as the sum of $100 \%$ of $R \& D$ expenditure in 2004 (2005), $80 \%$ of $R \& D$ expenditure in 2003 (2004), $60 \%$ of $R \& D$ expenditure in 2002 (2003), $40 \%$ of $R \& D$ expenditure in 2001 (2002) and 20\% of $R \& D$ expenditure in 2000 (2001) divided by total assets in 2004 (2005). Ownership is defined as the natural logarithm of the sum of the proportion of shares outstanding plus the proportion of shares outstanding in options times the Black-Scholes delta hedge ratio. Optimal is a dummy variable that takes the value of 1 if dividend payers belong to the More Optimal subsample and zero otherwise. Dividend payers belong to More Optimal if the difference in absolute value of Deviation in 2002 is greater than the absolute value of Deviation in 2004, where Deviation is the residuals obtained from the regression results of Equation 4. Size is natural logarithm of total market value where market value is the product of total common shares outstanding and the market price at fiscal year-end. MTB is the ratio of total market value to total assets. Leverage is total debt divided by total assets. Stock return volatility is the annualized standard deviation of stock returns estimated over the 60 months prior to the beginning of the fiscal year. Cash flow is the net cash flow scaled by total assets. Capital expenditure is the total capital expenditure scaled by total assets. Working capital is total working capital scaled by total assets. $p$-values are from one-tailed tests if a prediction is made and two-tailed tests otherwise.

Panel A of Table 6 presents the regression results of Equation 7 where the dependent variable measures the changes in accumulate $R \& D$ investment between 2002 and 2004. In Panel $\mathrm{B}$, the dependent variable is the difference between accumulative $R \& D$ investment between 2002 and 2005. Overall, the regression results of Equation 7 in both Panels A and B of Table 6 
indicate that changes in ownership is significantly associated with changes in the level of risky investment, as measured by accumulative $R \& D$ investment. It is interesting to note that although the CEO ownership of dividend payers increased significantly between 2002 and 2004 in both More Optimal and the Less Optimal subsamples, only CEOs in the Less Optimal subsample significantly reduced their $R \& D$ investments. One percent increase in ownership of the CEOs in the Less Optimal subsample is associated with the reduction in $R \& D$ investment equivalent to 0.25 (0.26) percent in 2004 (2005). In contrast, one percent increase in ownership of CEOs in the More Optimal subsample is associated with an insignificant decrease in $R \& D$ investment in 2004 (2005) equivalent to $0.05 \%(0.10 \%)$ of total assets value. In sum, I find results support my second hypothesis that changes in CEO ownership is associated with changes in the level of risky investment as measured by $R \& D$ investment in the Less Optimal subsample but not in the More Optimal subsample.

Since the ownership of non-dividend payers do not change significantly after the 2003 DTC, I do not expect to find a significant associated between changes in CEO ownership of nondividend payers and changes in their $R \& D$ investment decisions. I re-examine regression with changes in $R \& D$ is the dependent variable and changes in CEO Ownership, and changes in Size, MTB, Leverage, Stock return volatility, Cash flow, Capital expenditure and Working capital as explanatory variables. The untabulated regression results show that there is no statistical significant relation between changes in ownership and change in $R \& D$ investment in the sample of 297 non-dividend payers. 


\subsection{Impact on Investment Efficiency: Methodology and Results}

To test the third hypothesis, I use the difference-in-difference research design and compare the changes in $R \& D$ investment efficiency of dividend payers in the More and Less Optimal subsample between 2004 and 2006, and 2004 and 2007, respectively.

Table 7: $R \& D$ Investment Efficiency

\begin{tabular}{|c|c|c|c|}
\hline & $\begin{array}{c}\text { Investment Efficiency } \\
2004\end{array}$ & $\begin{array}{c}\text { Investment Efficiency } \\
2006\end{array}$ & $\begin{array}{c}\text { Investment Efficiency } \\
2007\end{array}$ \\
\hline \multicolumn{4}{|c|}{ Panel A: Total Sample $(N=156)$} \\
\hline $\begin{array}{l}\text { Total sample } \\
\text { Mean } \\
\text { ( } p \text {-value) } \\
\text { Median } \\
\text { ( } p \text {-value) }\end{array}$ & $\begin{array}{l}0.143 \\
0.082\end{array}$ & $\begin{array}{c}0.163 \\
(<0.0001) \\
0.083 \\
(0.25)\end{array}$ & $\begin{array}{c}0.151 \\
(<0.0001) \\
0.088 \\
(0.33)\end{array}$ \\
\hline \multicolumn{4}{|c|}{ Panel B: More Optimal Subsample $(N=77)$} \\
\hline $\begin{array}{l}\text { Mean } \\
(p \text {-value }) \\
\text { Median } \\
(p \text {-value })\end{array}$ & $\begin{array}{l}0.133 \\
0.068\end{array}$ & $\begin{array}{c}0.194 \\
(<0.0001) \\
0.084 \\
(<0.0001)\end{array}$ & $\begin{array}{c}0.163 \\
(<0.0001) \\
0.102 \\
(<0.0001)\end{array}$ \\
\hline \multicolumn{4}{|c|}{ Panel C: Less Optimal Subsample $(N=79)$} \\
\hline $\begin{array}{l}\text { Mean } \\
(p \text {-value }) \\
\text { Median } \\
(p \text {-value })\end{array}$ & $\begin{array}{l}0.134 \\
0.094\end{array}$ & $\begin{array}{c}0.132 \\
(0.444) \\
0.077 \\
(<0.0001)\end{array}$ & $\begin{array}{c}0.131 \\
(0.334) \\
0.073 \\
(<0.0001)\end{array}$ \\
\hline \multicolumn{4}{|c|}{ Panel D: Difference between More and Less Optimal Subsamples } \\
\hline $\begin{array}{l}\text { Mean } \\
(p \text {-value }) \\
\text { Median } \\
(p \text {-value })\end{array}$ & $\begin{array}{r}-0.001 \\
(0.951) \\
-0.026 \\
(0.0003)\end{array}$ & $\begin{array}{c}0.062 \\
(0.0006) \\
0.007 \\
(0.029)\end{array}$ & $\begin{array}{c}0.024 \\
(0.0008) \\
0.029 \\
(0.0014)\end{array}$ \\
\hline \multicolumn{4}{|c|}{$\begin{array}{l}\text { Note: This table reports the changes in Investment Efficiency of } 156 \text { dividend payers in 2004, } 2006 \text { and } 2007 . \\
\text { Investment Efficiency is measured by the number of granted patents scaled by two-year lag of the total 5-year } \\
\text { accumulative } R \& D \text { expenditure. Dividend payers are divided into two subsamples based on the change in Deviation } \\
\text { of CEO ownership between } 2002 \text { and 2004, where Deviation is the residuals obtained from the regression results of } \\
\text { Equation } 4 \text {. Dividend payers belong to the More Optimal subsample if the absolute value of Deviation in } 2002 \text { is } \\
\text { greater than that in } 2004 \text {. Dividend payers belong to the Less Optimal subsample if the absolute value of Deviation } \\
\text { in } 2002 \text { is less than that in 2004. Panel A reports Investment Efficiency of the total sample of } 156 \text { dividend payers. } \\
\text { Panels B (C) presents Investment Efficiency of } 77 \text { (79) dividend payers in the More (Less) Optimal subsample. The } \\
\text { two-tailed p-values reported in Panels A, B and C are from the tests of the change in Investment Efficiency from } \\
2004 \text { to } 2006 \text { and to 2007. Panel D reports difference in Investment Efficiency of dividend payers in the More } \\
\text { Optimal and Less Optimal subsamples with one-tailed p-values reported in parentheses. }\end{array}$} \\
\hline
\end{tabular}


To measure $R \& D$ investment efficiency, I follow Hirshleifer, Hsu and Li 2013) and define $R \& D$ investment efficiency as a firm's ability to generate patents per dollar of $R \& D$ expenditure (Hirshleifer, Hsu and Li 2013). Prior studies suggest that patents are the most important measure of Investment Efficiency (Lev 2001; Hirshleifer, Hsu and Li 2013). I also allow two-year lag between change in $R \& D$ investment and patents granted because on average it takes two years for the USPTO to grant a patent application (Hall, Jaffe and Trajtenberg 2001). Since I compute the change in $R \& D$ investment in 2004 and 2005, the two-year lag IE is measured in 2006 and 2007 are $I E_{2006}=\frac{\# \text { Patents }_{2006}}{R \& D_{2004}}$ and $I E_{2007}=\frac{\# \text { Patents }_{2007}}{R \& D_{2005}}$, respectively.

The test results for changes in investment efficiency using mean and median values are reported in Table 7. Panel A reports the difference-in-difference test using the total sample of 156 dividend payers. Compared to their IE 2004, dividend payers experienced significant increase in $I E$ in 2006 and 2007. One dollar invest in $R \& D$ in 2004 generated 0.163 patents granted in 2006 and one dollar invested in $R \& D$ in 2005 generated 0.151 patents granted in 2007. The improvement in $I E$ in 2006 and 2007 is statistically significant at mean level but is not significant different at median level.

It is interesting to observe that the results reported in Panels B and C of Table 7 suggest that the improvement in $I E$ of dividend payers is driven by the firms in the More Optimal subsample not the firms in the Less Optimal subsample. The dividend payers in the More Optimal subsample experienced consistent improvement in IE in 2006 and 2007 while the dividend payers in the Less Optimal subsample experienced a small reduction in IE in 2006 and 2007 at mean level and significant reduction in $I E$ in 2006 and 2007 at median levels. It is worth to underscore that the changes in $I E$ in 2006 and 2007 of dividend payers are not mechanically 
driven by the fact that these companies increase (or decrease) their investment in $R \& D$ because $I E$ is measured as number patents granted per each dollar invested in $R \& D$. Compared to dividend payers in the Less Optimal subsample, each dollar invested in R\&D investment of dividend payers in the More Optimal subsample generated 6.2\% more patents in 2006 and $2.4 \%$ more patents in 2007 (Panel D, Table 7). Thus, the results support my third hypothesis that more optimal ownership is associated with more efficient risky investment.

\subsection{Impact on Firm Performance: Methodology and Results}

In previous sections of this study, first, I document that CEO ownership of dividend payers significantly increased after the 2003 DTC. Then, I find that the increase in CEO ownership of dividend payers has asymmetric impact on risky investment decisions (measured by $R \& D$ investment) and on investment efficiency (measured by the number of patents granted). Only the dividend payers whose CEO ownership moved closer to the optimal level of ownership experienced an increase in $R \& D$ investment and in investment efficiency. The dividend payers whose CEO ownership moved further from the optimal level of ownership after the 2003 DTC experienced a significant reduction in $R \& D$ investment and investment efficiency.

In this section, I aim to examine whether more optimal ownership is associated with better firm performance through investment efficiency improvement. To test the last hypothesis that higher investment efficiency is associated better firm performance, I first look at whether the accounting operating performance measured by return on asset $(R O A)$ is statistically positive when the investment outcomes are observed (in 2006 and 2007). I follow the suggestion of Barber and Lyon (1996) to develop a comparison benchmark by using the industry and performance match. For each dividend payer in my sample, I select a match firm in the same 2 
digit SIC industry with the closest accounting operating performance in 2004. I also require that the control firm's $R O A$ be between 90 percent and 110 percent of the dividend payer's $R O A$. The process yields 227 control firms satisfying the matching requirements. To provide robustness for the test, I compute ROA using both operating income after depreciation and operating income before depreciation.

My matching procedure is successful in creating a match sample whose 2004 operating performance is insignificantly different from that of the dividend payers in my sample of interest. The Excess ROA in 2004 and 2005 of 227 dividend payers is insignificantly different from zero. Overall, dividend payers underperformed their benchmark firms in 2006 but outperformed their benchmark firms in 2007 at both mean and median levels (Panel A, Table 8). On average, in 2006, dividend payers statistically underperformed the $R O A$ of the benchmark firms by a mean (median) of 0.31 (0.09) percentage points. In 2007, dividend payers outperformed the ROA of their benchmark firms by a mean (median) of $0.71(0.53)$ percentage points. I obtain similar results when using operating income before depreciation to compute $R O A$. 
Table 8: Operating Performance - Excess ROA

\begin{tabular}{cccccc}
\hline \hline Year & $\mathbf{N}$ & Mean & $\boldsymbol{p}$-value & Median & $\boldsymbol{p}$-value \\
\hline$(1)$ & $(2)$ & $(3)$ & $(4)$ & $(5)$ & $(6)$ \\
\hline \multicolumn{7}{l}{ Panel A: Total dividend payer sample } \\
\multicolumn{7}{l}{ Excess ROA computed using operating } & income before depreciation \\
2004 & 227 & $0.00 \%$ & 0.93 & $0.00 \%$ & 0.76 \\
2005 & 227 & $0.57 \%$ & 0.77 & $-0.37 \%$ & 0.11 \\
2006 & 226 & $-0.31 \%$ & 0.09 & $-0.09 \%$ & 0.17 \\
2007 & 226 & $0.71 \%$ & 0.0003 & $0.53 \%$ & 0.0001 \\
Excess ROA computed using operating income after depreciation & & & \\
2004 & 227 & $0.00 \%$ & 0.85 & $0.00 \%$ & 0.61 \\
2005 & 227 & $-0.82 \%$ & 0.76 & $-0.52 \%$ & 0.09 \\
2006 & 226 & $-0.13 \%$ & 0.08 & $-0.21 \%$ & 0.09 \\
2007 & 226 & $0.36 \%$ & 0.07 & $0.32 \%$ & 0.10 \\
\hline
\end{tabular}

Panel B: Dividend payer-More Optimal subsample

Excess ROA computed using operating income before depreciation

$\begin{array}{lllllc}2004 & 105 & 0.01 \% & 0.57 & 0.00 \% & 0.15 \\ 2005 & 105 & 0.22 \% & 0.35 & 0.13 \% & 0.28 \\ \mathbf{2 0 0 6} & \mathbf{1 0 5} & \mathbf{1 . 3 8 \%} & <\mathbf{0 . 0 0 0 1} & \mathbf{0 . 9 2 \%} & <\mathbf{0 . 0 0 0 1} \\ \mathbf{2 0 0 7} & \mathbf{1 0 5} & \mathbf{1 . 9 5 \%} & \mathbf{< 0 . 0 0 0 1} & \mathbf{1 . 9 1 \%} & <\mathbf{0 . 0 0 0 1}\end{array}$

Excess ROA computed using operating income after depreciation

$\begin{array}{cccccc}2004 & 105 & 0.01 \% & 0.60 & 0.00 \% & 0.38 \\ 2005 & 105 & 0.13 \% & 0.58 & 0.06 \% & 0.83 \\ \mathbf{2 0 0 6} & \mathbf{1 0 5} & \mathbf{1 . 1 0 \%} & <\mathbf{0 . 0 0 0 1} & \mathbf{0 . 6 0 \%} & \mathbf{0 . 0 0 1 3} \\ \mathbf{2 0 0 7} & \mathbf{1 0 5} & \mathbf{1 . 7 1 \%} & \mathbf{0 . 0 8} & \mathbf{1 . 4 1 \%} & \mathbf{0 . 1 0}\end{array}$

Panel C: Dividend payer - Less Optimal subsample

Excess ROA computed using operating income before depreciation

$\begin{array}{cccccc}2004 & 122 & 0.02 \% & 0.69 & 0.00 \% & 0.42 \\ 2005 & 122 & -1.16 \% & <0.0001 & -0.81 \% & <0.0001 \\ \mathbf{2 0 0 6} & \mathbf{1 2 1} & \mathbf{- 0 . 6 7 \%} & \mathbf{0 . 0 0 2} & \mathbf{- 0 . 6 0 \%} & \mathbf{0 . 0 0 2} \\ \mathbf{2 0 0 7} & \mathbf{1 2 1} & \mathbf{- 0 . 4 1 \%} & \mathbf{0 . 1 0} & \mathbf{- 0 . 3 4 \%} & \mathbf{0 . 0 6}\end{array}$

Excess ROA computed using operating income after depreciation

$\begin{array}{cccccc}2004 & 122 & -0.11 \% & 0.49 & -0.02 \% & 0.29 \\ 2005 & 122 & -1.64 \% & <0.0001 & -0.88 \% & <0.0001 \\ \mathbf{2 0 0 6} & \mathbf{1 2 1} & \mathbf{- 1 . 2 0 \%} & <\mathbf{0 . 0 0 0 1} & \mathbf{- 0 . 9 8 \%} & <\mathbf{0 . 0 0 0 1} \\ \mathbf{2 0 0 7} & \mathbf{1 2 1} & \mathbf{- 0 . 8 7 \%} & \mathbf{0 . 0 0 7} & \mathbf{- 0 . 8 4 \%} & \mathbf{0 . 0 0 6}\end{array}$

Panel D: Difference between More Optimal and Less Optimal subsamples

ROA computed using operating income before depreciation

\begin{tabular}{lccccc}
2004 & $105 / 122$ & $0.30 \%$ & 0.38 & $0.51 \%$ & 0.62 \\
2005 & $105 / 122$ & $0.98 \%$ & 0.002 & $0.35 \%$ & 0.13 \\
$\mathbf{2 0 0 6}$ & $\mathbf{1 0 5} / \mathbf{1 2 1}$ & $\mathbf{1 . 4 9 \%}$ & $\mathbf{< 0 . 0 0 0 1}$ & $\mathbf{1 . 0 6 \%}$ & $<\mathbf{0 . 0 0 0 1}$ \\
$\mathbf{2 0 0 7}$ & $\mathbf{1 0 5 / 1 2 1}$ & $\mathbf{1 . 7 8 \%}$ & $\mathbf{< 0 . 0 0 0 1}$ & $\mathbf{2 . 0 4 \%}$ & $<\mathbf{0 . 0 0 0 1}$ \\
computed using & operating income after & depreciation & & & \\
2004 & $105 / 122$ & 0.61 & 0.07 & $1.18 \%$ & 0.30 \\
2005 & $105 / 122$ & $1.29 \%$ & $<0.0001$ & $0.67 \%$ & 0.01 \\
$\mathbf{2 0 0 6}$ & $\mathbf{1 0 5 / 1 2 1}$ & $\mathbf{1 . 6 8 \%}$ & $<\mathbf{0 . 0 0 0 1}$ & $\mathbf{0 . 9 2 \%}$ & $<\mathbf{0 . 0 0 0 1}$ \\
$\mathbf{2 0 0 7}$ & $\mathbf{1 0 5} / \mathbf{1 2 1}$ & $\mathbf{1 . 9 5 \%}$ & $\mathbf{< 0 . 0 0 0 1}$ & $\mathbf{1 . 7 1 \%}$ & $<\mathbf{0 . 0 0 0 1}$ \\
\hline
\end{tabular}

Note: This table presents excess operating performance of dividend papers between 2004 and 2007. I calculate excess ROA by using the matched-firm approach of Barber and Lyon (1996), where the matching firm is non- 
dividend paying firm in the same 2-digit SIC industry with the closest operating performance in 2004 and by using both operating income after depreciation and operating income before depreciation. The total matched sample consists of 227 dividend payers and non-dividend payer pairs matched in 2004. Panel A presents excess operating performance of dividend payers compared to their matched non-dividend payers. Panel B (C) presents excess operating performance of dividend payers in More (Less) Optimal subsample. I use the difference in absolute value of Deviation in 2002 and that in 2004 to separate 227 dividend payers into 105 More Optimal and 122 Less Optimal firms. Deviation is the residuals obtained from the regression results of Equation 4. Firms belong to More Optimal subsample if the absolute value of Deviation in 2002 is greater than the absolute value of Deviation in 2004. Firms belong to Less Optimal subsample if the absolute value of Deviation in 2002 is less than the absolute value of Deviation in 2004. Panel D presents the difference in operating performance between dividend payers in More and Less Optimal subsamples.

After separating dividend payers into two subsamples, the More and Less Optimal subsamples, I observe significantly different results. Only firms in the More Optimal subsample consistently outperformed their benchmark firms in 2006 and 2007. More Optimal ownership is associated with consistent improvement in operating performance. Dividend payers in More Optimal subsample statistically outperformed the ROA of their benchmark firms in 2006 by a mean (median) of $1.38(0.92)$ percentage points and in 2007 by a mean (median) of 1.95 (1.91) percentage points. In contrast, dividend payers in Less Optimal subsample statistically underperformed the ROA of their benchmark firms in 2006 by a mean (median) of $0.67(0.60)$ percentage points and then continued to underperform by a mean (median) of $0.87(0.84)$ percentage points in 2007. Comparing the ROA between dividend payers in More and Less Optimal subsamples, I find that on average the More Optimal dividend payers consistently beat the Less Optimal dividend payers in 2006 and 2007 by 1.49 and 1.78 percentage points, accordingly. The results are robust when $R O A$ is computed by using income before depreciation and using income after depreciation. These results are consistent with the last hypothesis that investment efficiency is positively associated with firm performance.

In the second test of the last hypothesis, I assess whether the stock price returns of dividend payers in my sample statistically positive over the 12- and 24-month periods after the 
improvement in investment efficiency is observed. I follow Barber and Lyon (1997) and Mitchell and Stafford (2000) and use buy-and-hold excess returns (Excess BHAR) to measure long-term stock performance as follow:

$$
B H A R_{i}=\prod_{t=1}^{T}\left(1+R_{i t}\right)-\prod_{t=1}^{T}\left(1+R_{\text {Portfolio }, t}\right)
$$

where the indices $i$ and $t$ correspond to firm and month, respectively, $R$ is monthly return. The first month, $t=1$, is the first month in fiscal year 2006. I create a matching portfolio for each dividend payers in my sample from a list of all CRSP firms based on size measured as market value as of the end of June 2006 and book-to-market equity (BTM) as of the last book value reported prior to June 2006. I follow Fama and French (1997) and define book equity as total shareholders' equity, minus preferred stock, plus deferred taxes, plus investment tax credit, plus postretirement benefit liabilities. Missing data are set to zero. Each dividend payer is matched to its corresponding portfolios using the $5 \times 5$ size/BTM breakpoints from Dr. Kenneth French's website. ${ }^{10}$ Delisted firms are retained during 2006 and 2007 to avoid survivorship bias by including delisting returns and investing the proceeds in the matching size/BTM portfolio. Then, I follow Mitchell and Stafford (2000) and compute the value-weighted average of the individual BHARs based on market value at the end of 2005 , scaled by the level of the CRSP valueweighted weights. This procedure eliminates the problem arising from unstandardized value weights that over-weight more recent observations. Out of 247 dividend payers, 226 firms have data available to use in the matching process.

\footnotetext{
${ }^{10} \mathrm{http}: / /$ mba.tuck.dartmouth.edu/pages/faculty/ken.french/data_library.html
} 
Table 9: Stock Performance

\begin{tabular}{|c|c|c|c|c|c|}
\hline Year & $\mathbf{N}$ & $\begin{array}{c}\text { Mean } \\
B H A R\end{array}$ & $p$-value & $\begin{array}{c}\text { Median } \\
B H A R\end{array}$ & $p$-value \\
\hline$(1)$ & $(2)$ & (3) & (4) & $(5)$ & $(6)$ \\
\hline \multicolumn{6}{|c|}{ Panel A: Total dividend payer sample } \\
\hline 2006 & 226 & $2.72 \%$ & 0.05 & $0.92 \%$ & 0.25 \\
\hline 2006 and 2007 & 224 & $4.79 \%$ & 0.05 & $1.85 \%$ & 0.27 \\
\hline \multicolumn{6}{|c|}{ Panel B: Dividend payer-More Optimal subsample } \\
\hline 2006 & 105 & $5.36 \%$ & 0.01 & $2.18 \%$ & 0.03 \\
\hline 2006 and 2007 & 105 & $7.57 \%$ & 0.04 & $2.38 \%$ & 0.04 \\
\hline \multicolumn{6}{|c|}{ Panel C: Dividend payer-Less Optimal subsample } \\
\hline 2006 & 121 & $-0.46 \%$ & 0.81 & $-0.66 \%$ & 0.51 \\
\hline 2006 and 2007 & 119 & $0.52 \%$ & 0.59 & $-0.32 \%$ & 0.66 \\
\hline \multicolumn{6}{|c|}{ Panel D: Difference between More Optimal and Less Optimal subsamples } \\
\hline 2006 & $105 / 121$ & $5.82 \%$ & $<0.001$ & $2.84 \%$ & 0.02 \\
\hline 2006 and 2007 & $105 / 119$ & $7.05 \%$ & 0.004 & $2.70 \%$ & 0.05 \\
\hline
\end{tabular}

Note: This table presents the stock market performance of dividend payers in 2006 and 2007. I calculate excess stock returns using portfolio-matched-buy and hold abnormal returns (BHARs), where return benchmark is the returns on corresponding value-weighted size and book to market portfolio constructed by Fama and French 1993. Panel A reports the mean and median values of excess BHAR of total dividend payers. Panel B (C) reports the mean and median values of excess BHAR of dividend payers in subsample of More (Less) Optimal. Panel D presents the test statistics of the differences in BHAR at mean and median values between dividend payers in More and Less Optimal subsamples. I use the difference in absolute value of Deviation in 2002 and that in 2004 to separate the 213 dividend payers into two subsamples More and Less Optimal subsamples, where Deviation is the residuals obtained from the regression results of Equation4. Dividend payers belong to More Optimal subsample if the absolute value of Deviation in 2002 is greater than the absolute value of Deviation in 2004. Dividend payers belong to Less Optimal subsample if the absolute value of Deviation in 2002 is less than the absolute value of Deviation in 2004.

Table 9 presents the stock return performance results. Dividend payers in More Optimal subsample statistically outperformed their benchmark portfolios in 2006 and 2007 with a mean Excess BHAR of 5.36 percent and 7.57 percent, respectively, and a median of 2.18 percent and 2.38 percent, respectively (Panel B, Table 9). In contrast, the Excess BHARs of dividend payers in Less Optimal subsample are $-0.46 \%$ at mean level and $-0.66 \%$ at median level of 2006 , and $0.52 \%$ at mean level and $-0.32 \%$ at median level in 2007 (Panel C, Table 9). Compare to dividend payers in the Less Optimal subsample, dividend payers in the More Optimal subsample consistently outperformed by 5.82\% in 2006 and $7.05 \%$ in 2006 and 2007. 
In sum, the results reported in Tables 8 and 9 support my last hypothesis that higher investment efficiency is significantly associated with better firm performance. My empirical results are in line with the evidences documented in Hirshleifer, Hsu and Li (2013). 


\section{Summary and Conclusions}

This study examines the relation between CEO ownership and firm performance using a large tax cut on dividend income enacted in 2003 (the 2003 DTC) as an exogenous shock. The 2003 DTC significantly increased the value of dividend income by $38 \%$ from tax savings. I document that the 2003 DTC has a significantly positive shock on CEO ownership of firms that pay dividends (dividend payers) by increasing their CEO ownership from 6.73\% in 2002 to $11.41 \%$ in 2004. The increase in CEO ownership of dividend payers come from three difference channels: new restricted stock grants in annual compensation package, stock options exercised by CEOs, and net positive open-market trading by CEOs.

Following the theoretical framework developed in Core and Guay (1999) and Core and Larcker (2002), I expect that more optimal ownership is associated with improvement in firm performance. I argue that higher ownership does not necessarily lead to better performance. It is the optimal level of ownership that determines firm performance and one of the important channels to improve firm performance is improvement in $R \& D$ investment.

I follow Core and Guay (1999) and define CEO ownership as the natural logarithm of the proportion of shares outstanding held by a CEO plus the proportion of shares outstanding in options held by a CEO times the Black-Scholes hedging delta. Using an optimal ownership model as a benchmark, I measure the change in distance to optimal ownership level for CEOs of dividend payers between 2002 and 2004 (one year pre- and post-the 2003 DTC). I develop an ownership benchmark by constructing a regression model comparable to those models used by Himmelberg, Hubbard and Palia (1999) and Core and Larcker (2002) where the dependent

variable in the regression is the natural logarithm of CEO Ownership. Dividend payers in my 
data sample are divided into two subsamples: More Optimal and Less Optimal based on the changes in the absolute value of the residuals obtained from the ownership benchmark regression. Firms belong to More Optimal subsample if the absolute value of Deviation in 2002 is greater than the absolute value of Deviation in 2004. Firms belong to Less Optimal subsample if the absolute value of Deviation in 2002 is less than the absolute value of Deviation in 2004.

I first document that the 2003 DTC has a positive impact on CEO ownership of dividend payers in both the More and Less Optimal subsample. However, the increase in CEO ownership has asymmetric impact on risky investment decision and investment efficiency outcomes in each subsample. Using difference-in-difference approach to examine the change in $R \& D$ investment efficiency measured by the number of patents granted per each dollar of $R \& D$ investment, I find that More Optimal dividend payers experienced significant improvement in investment efficiency and firm performance (measured by ROA and BHARs) while Less Optimal dividend payers did not.

This paper contributes to the extant literature in several important ways. First, this paper extends the literature on the relation between managerial equity ownership and firm performance by showing that CEO ownership is significantly associated with firm performance through the improvement in risky investment decisions. My empirical results shed light on the theoretical prediction of the optimal ownership model developed by Core and Guay (1999) that higher ownership does not always lead to improvement in firm performance. It is the distance to optimal ownership level that is the important determinant of firm performance improvement. More optimal ownership is associated with improvement in risky investment decisions and firm performance. Second, I provide empirical evidences on how CEO ownership increased after the 2003 DTC. My results show that CEO ownership increased after the 2003 DTC through new 
restricted stock grants, more option exercised by CEOs and positive net open-market trading by CEOs. Third, my findings that higher CEO ownership has an asymmetric impact of risky investment extend the findings documented in Coles, Daniel and Naveen (2006). I document that although dividend payers in the More and Less Optimal subsamples both significantly reduced option grants after the 2003 DTC, only dividend payers in the Less Optimal subsample reduced their investment in $R \& D$. In contrast, dividend payers in the More Optimal subsample even increased their $R \& D$ investment. My findings highlight the importance of the prior level of CEO ownership before the shock and the distance to optimal ownership in determining risk-taking behaviors of CEOs. This study also extends the findings of Coles, Daniel and Naveen (2006) by providing empirical evidences about the outcome of the changes in CEOs' risk taking decisions. Last but not least, the paper extends a growing literature on the impacts of dividend taxes on corporate behaviors by showing that changes in dividend taxes have significant impact on compensation decisions by boards of directors and on the total equity ownership of CEOs. Tax policy makers, corporate board of directors, shareholders, academic researchers and those who are interested in the relation between executive compensation and firm performance would find the findings of this study interesting and meaningful. 


\section{References}

Aboody, David, and Ron Kasznik. "Executive stock-based compensation and firms' cash payout: the role of shareholders' tax-related payout preferences."Review of Accounting Studies 13.2-3 (2008): 216-251.

Amromin, Gene, Paul Harrison, and Steven Sharpe. "How did the 2003 dividend tax cut affect stock prices?." Financial Management 37.4 (2008): 625-646.

Auerbach, A. J., \& Hassett, K. A. (2005). The 2003 dividend tax cuts and the value of the firm: An event study (No. w11449). National Bureau of Economic Research.

Barber, Brad M., and John D. Lyon. "Detecting abnormal operating performance: The empirical power and specification of test statistics." Journal of financial Economics 41.3 (1996): 359-399.

Barber, Brad M., and John D. Lyon. "Detecting long-run abnormal stock returns: The empirical power and specification of test statistics." Journal of financial economics 43.3 (1997): 341-372.

Becker, Bo, Marcus Jacob, and Martin Jacob. "Payout taxes and the allocation of investment." Journal of Financial Economics 107.1 (2013): 1-24.

Black, Fischer, and Myron Scholes. "The pricing of options and corporate liabilities." The journal of political economy (1973): 637-654.

Blouin, Jennifer L., Jana S. Raedy, and Douglas A. Shackelford. "Dividends, share repurchases, and tax clienteles: Evidence from the 2003 reductions in shareholder taxes." The Accounting Review 86.3 (2011): 887-914.

Brav, A., Graham, J. R., Harvey, C. R., \& Michaely, R. (2008). Managerial response to the May 2003 dividend tax cut. Financial management, 37(4), 611-624.

Brown, J. R., Liang, N., \& Weisbenner, S. (2007). Executive financial incentives and payout policy: Firm responses to the 2003 dividend tax cut. The Journal of Finance, 62(4), 1935-1965.

Campbell, J. L., Chyz, J. A., Dhaliwal, D. S., \& Schwartz Jr, W. C. (2013). Did the 2003 tax act increase capital investments by corporations?. The Journal of the American Taxation Association, 35(2), 33-63.

Chan, L. K., Lakonishok, J., \& Sougiannis, T. (2001). The Stock Market Valuation of Research and Development Expenditures. The Journal of Finance, 56(6).

Cheng, Q., \& Farber, D. B. (2008). Earnings restatements, changes in CEO compensation, and firm performance. The Accounting Review, 83(5), 1217-1250. 
Cheng, Q., \& Warfield, T. D. (2005). Equity incentives and earnings management. The accounting review, 80(2), 441-476.

Chetty, R., Rosenberg, J., \& Saez, E. (2005). The Effects of Taxes on Market Responses to Dividend Announcements and Payments: What Can We Learn from the 2003 Dividend Tax Cut? (No. w11452). National Bureau of Economic Research.

Chetty, R., \& Saez, E. (2005). Dividend Taxes and Corporate Behavior: Evidence from the 2003 Dividend Tax Cut. The Quarterly Journal of Economics,120(3), 791-833.

Chetty, R., \& Saez, E. (2006). The effects of the 2003 dividend tax cut on corporate behavior: Interpreting the evidence. The American economic review, 124-129.

Coles, J. L., Daniel, N. D., \& Naveen, L. (2006). Managerial incentives and risk-taking. Journal of Financial Economics, 79(2), 431-468.

Coles, J. L., Lemmon, M. L., \& Meschke, J. F. (2012). Structural models and endogeneity in corporate finance: The link between managerial ownership and corporate performance. Journal of Financial Economics, 103(1), 149-168.

Core, J., \& Guay, W. (1999). The use of equity grants to manage optimal equity incentive levels. Journal of accounting and economics, 28(2), 151-184.

Core, J. E., \& Larcker, D. F. (2002). Performance consequences of mandatory increases in executive stock ownership. Journal of Financial Economics, 64(3), 317-340.

Dai, Z., Shackelford, D. A., Zhang, H. H., \& Chen, C. (2013). Does Financial Constraint Affect the Relation between Shareholder Taxes and the Cost of Equity Capital?. The Accounting Review, 88(5), 1603-1627.

Demsetz, H., \& Lehn, K. (1985). The structure of corporate ownership: Causes and consequences. The Journal of Political Economy, 1155-1177.

Dhaliwal, Dan, Linda Krull, and Oliver Zhen Li. "Did the 2003 Tax Act reduce the cost of equity capital?." Journal of Accounting and Economics 43.1 (2007): 121-150.

Duong, H. K., G. Gotti, \& D. B. Farber (2016). Managerial Hedging, Changes in Optimal Ownership, and Firm Performance. (working paper at The University of Texas at El Paso)

Edgerton, Jesse. "Four facts about dividend payouts and the 2003 tax cut."International Tax and Public Finance 20.5 (2013): 769-784.

Faccio, Mara, and Jin Xu. "Taxes and capital structure." Journal of Financial and Quantitative Analysis 50.03 (2015): 277-300. 
Fama, Eugene F., and Kenneth R. French. "Common risk factors in the returns on stocks and bonds." Journal of Financial Economics 33.1 (1993): 3-56.

Fama, Eugene F., and Kenneth R. French. "Industry costs of equity." Journal of Financial Economics 43.2 (1997): 153-193.

Hanlon, Michelle, and Jeffrey L. Hoopes. "What do firms do when dividend tax rates change? An examination of alternative payout responses." Journal of Financial Economics 114.1 (2014): 105-124.

Heckman, J. J. (1979). Sample selection bias as a specification error. Econometrica: Journal of the econometric society, 153-161.

Himmelberg, C. P., Hubbard, R. G., \& Palia, D. (1999). Understanding the determinants of managerial ownership and the link between ownership and performance. Journal of financial economics, 53(3), 353-384.

Hirshleifer, D., Hsu, P. H., \& Li, D. (2013). Innovative efficiency and stock returns. Journal of Financial Economics, 107(3), 632-654.

Jensen, M. C., \& Meckling, W. H. (1976). Theory of the firm: Managerial behavior, agency costs and ownership structure. Journal of financial economics, 3(4), 305-360.

Kawano, Laura. "The dividend clientele hypothesis: Evidence from the 2003 tax act." American Economic Journal: Economic Policy 6.1 (2014): 114-136.

Kogan, L., Papanikolaou, D., Seru, A., \& Stoffman, N. (2012). Technological innovation, resource allocation, and growth (No. w17769). National Bureau of Economic Research.

Lambert, Richard A., William N. Lanen, and David F. Larcker. "Executive stock option plans and corporate dividend policy." Journal of financial and quantitative analysis 24.04 (1989): 409425.

Lev, B., Sarath, B., \& Sougiannis, T. (2005). R\&D Reporting Biases and Their Consequences. Contemporary Accounting Research, 22(4), 977-1026.

Lin, Leming, and Mark J. Flannery. "Do personal taxes affect capital structure? Evidence from the 2003 tax cut." Journal of Financial Economics109.2 (2013): 549-565.

Lyon, John D., Brad M. Barber, and Chih-Ling Tsai. "Improved methods for tests of long-run abnormal stock returns." The Journal of Finance 54.1 (1999): 165-201.

Minnick, Kristina, and Leonard Rosenthal. "Stealth compensation: Do CEOs increase their pay by influencing dividend policy?." Journal of Corporate Finance 25 (2014): 435-454. 
Mitchell, Mark L., and Erik Stafford. "Managerial Decisions and Long-Term Stock Price Performance*." The Journal of Business 73.3 (2000): 287-329.

Morck, R., Shleifer, A., \& Vishny, R. W. (1988). Management ownership and market valuation: An empirical analysis. Journal of financial economics, 20, 293-315.

Murphy, K. J. (1999). Executive compensation. In Handbook of labor economics,3, 2485-2563, edited by O.Ashenfleter and D.Card. Amsterdam, The Neitherlands: North Holland.

Ofek, E., \& Yermack, D. (2000). Taking stock: Equity-based compensation and the evolution of managerial ownership. The Journal of Finance, 55(3), 1367-1384.

Rajgopal, Shivaram, and Terry Shevlin. "Empirical evidence on the relation between stock option compensation and risk taking." Journal of Accounting and Economics 33.2 (2002): 145171.

Stinson R. S. \& Ricketts C. R. (2016) Shifts in Ownership Composition and Changes in the Implied Cost of Equity Capital for Dividend and Non-Dividend Stocks Following JGTRRA03. The Journal of the American Taxation Association: Spring 2016, Vol. 38, No. 1, pp. 103-124.

Stulz, R. (1988). Managerial control of voting rights: Financing policies and the market for corporate control. Journal of financial Economics, 20, 25-54.

Thornock, Jacob. "The effects of dividend taxation on short selling and market quality." The Accounting Review 88.5 (2013): 1833-1856.

Tong, Z. (2008). Deviations from optimal CEO ownership and firm value.Journal of Banking \& Finance, 32(11), 2462-2470.

White House. 2003. Fact sheet: President Bush Taking Action to Strengthen America's Economy (January 7). Available at https://georgewbush-

whitehouse.archives.gov/news/releases/2003/01/20030107.html

Yagan, Danny. Capital tax reform and the real economy: The effects of the 2003 dividend tax cut. No. w21003. National Bureau of Economic Research, 2015.

Zhou, X. (2001). Understanding the determinants of managerial ownership and the link between ownership and performance: comment. Journal of financial economics, 62(3), 559-571. 


\section{Vita}

Hong Kim Duong is a Ph.D. candidate in the Business Administration, concentration in Accounting at College of Business Administration, the University of Texas at El Paso. Her research interests include financial accounting, corporate governance, executive compensation and international accounting. She has published in Journal of International Accounting Research, Quarterly Journal of Finance, Managerial Finance and Journal of Accounting and Finance and presented her research at multiple national conferences in accounting and finance. She has taught Micro Economics and Principles Accounting courses at the University of Texas at El Paso.

Hong Kim Duong is originally from Hanoi, Vietnam. She completed her undergraduate degree Summa Cum Laude in English Business Administration at Foreign Trade University. After coming to the U.S. she completed her M.B.A. with concentration in Finance at the University of Texas at El Paso.

Contact Information: hkduong@utep.edu

This thesis/dissertation was typed by Hong Kim Duong. 